\title{
REVIEW
}

\section{Endocrinological derangements in COPD}

\author{
F. Laghi, N. Adiguzel and M.J. Tobin
}

ABSTRACT: Chronic obstructive pulmonary disease (COPD) is no longer considered to affect only the lungs and airways but also the rest of the body. The systemic manifestations of COPD include a number of endocrine disorders, such as those involving the pituitary, the thyroid, the gonads, the adrenals and the pancreas.

The mechanisms by which COPD alters endocrine function are incompletely understood but likely involve hypoxaemia, hypercapnia, systemic inflammation and glucocorticoid administration. Altered endocrine function can worsen the clinical manifestations of COPD through several mechanisms, including decreased protein anabolism, increased protein catabolism, nonenzymatic glycosylation and activation of the rennin-angiotensin-aldosterone system.

Systemic effects of endocrine disorders include abnormalities in control of breathing, decreases in respiratory and limb-muscle mass and function, worsening of respiratory mechanics, impairment of cardiac function and disorders of fluid balance.

Research on endocrine manifestations of COPD embraces techniques of molecular biology, integrative physiology and controlled clinical trials. A sound understanding of the various disorders of endocrine function associated with COPD is prudent for every physician who practices pulmonary medicine.

KEYWORDS: Aldosterone, diaphragm contractility, insulin-like growth factor-I, oestrogens, testosterone, thyroid

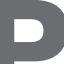
atients with chronic obstructive pulmonary disease (COPD) have a chronic illness. They are commonly hypoxaemic, hypercapnic or both, have increased levels of systemic inflammatory markers, and receive glucocorticoids. Each of these factors can affect endocrine function. In turn, altered endocrine function can worsen COPD through several mechanisms. Systemic effects of endocrinopathies triggered by COPD (or therapies used in COPD) include abnormalities in control of breathing, decreases in respiratory and limb-muscle mass and function, worsening of respiratory mechanics, impaired cardiac function, and abnormal fluid balance. In this review, we discuss endocrinopathies triggered by COPD, such as those involving the pituitary, the thyroid, the gonads, the adrenals and the pancreas. Areas of active research and controversial topics are specifically highlighted.

\section{COPD AND THE SOMATOTROPIC AXIS}

Weight loss and muscle wasting are present in about $20 \%$ of stable outpatients with COPD [1], $40 \%$ of patients with acute respiratory failure and $70 \%$ of patients requiring mechanical ventilation [2]. A decrease in fat-free mass is accompanied by a decrease in muscle mass (sarcopenia) $[2,3]$. The control of muscle mass is complex and includes the action of inflammatory cytokines, mechanical load on the muscles and anabolic hormones [4-6]. There are four main anabolic axes: somatotropic, gonadal, adrenal and insulin [4-8].

Central to the somatotropic axis are growth hormone $(\mathrm{GH})$ and insulin-like growth factor (IGF)-I. GH is released by the hypophysis and stimulates production of IGF-I. The major source of GH-dependent (and insulin-dependent) IGF-I production is the liver (circulating isoforms) [9] however, other tissues, including the skeletal muscles and the adipose tissue, produce both local and circulating isoforms of IGF-I [6].

Although the GH/IGF-I axis is often considered a major regulator of muscle mass, there is accumulating evidence that IGF-I also acts independently of GH [10]. The role of locally versus systemically produced IGF-I in determining muscle mass is not clear [11, 12]. IGF-I stimulates muscle protein synthesis and hypertrophy, and inhibits protein catabolism via the phosphatidylinositol 3-kinase (PI3K)/Akt (also called protein kinase B) pathway (fig. 1) [16].

\section{AFFILIATIONS}

Division of Pulmonary and Critical Care Medicine, Edward Hines Jr. Veterans Administration Hospital, and Loyola University of Chicago Stritch School of Medicine, Hines, IL, USA

\section{CORRESPONDENCE}

F. Laghi

Division of Pulmonary and Critical

Care Medicine

Edward Hines, Jr. VA Hospital $111 \mathrm{~N}$

5th Avenue and Roosevelt Road Hines

IL 60141

USA

E-mail: flaghi@lumc.edu

Received:

July 072008

Accepted after revision:

May 012009 


\section{COPD and depression of the somatotropic axis: risk factors} Advanced age, malnutrition, inactivity and administration of glucocorticoids are associated with downregulation of the GH/IGF-I system. In contrast, hypoxaemia and hypercapnia probably increase GH levels in patients with COPD [18, 19].

\section{Ageing}

Most patients with COPD are old, and ageing is associated with progressive decrease in muscle mass [20]. The mechanisms responsible for age-related decrease in muscle mass probably include decreases in GH/IGF-I [21-23], testosterone $[21,23,24]$ and dehydroepiandrosterone sulfate (DHEAS) [7].
Inactivity

In animal models of inactivity, loss of muscle mass has been associated with a decrease in IGF-I mRNA [25]. In patients with COPD, inactivity has been implicated in the reduction of quadriceps muscle expression of IGF-I and of myogenic differentiation protein $(\mathrm{MyoD})$ : a transcription factor required to maintain stable skeletal muscle differentiation and to induce proliferation and repair by satellite cells in response to muscle injury [10].

\section{Malnutrition}

Malnutrition can decrease serum levels of IGF-I [11, 26, 27]. In laboratory animals, malnutrition can also decrease IGF-I a)

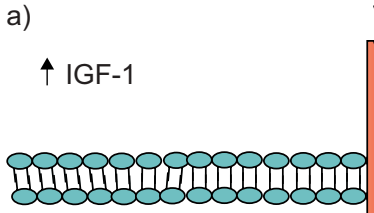

Cytosol
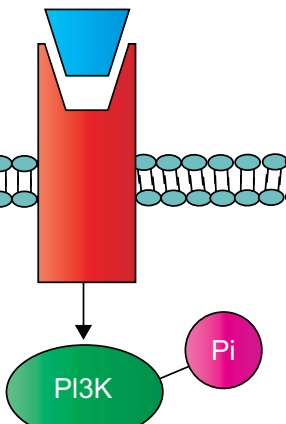

Activation
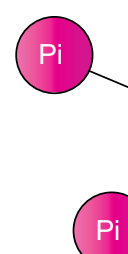<smiles></smiles>

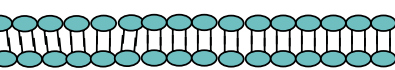
0000000000000000
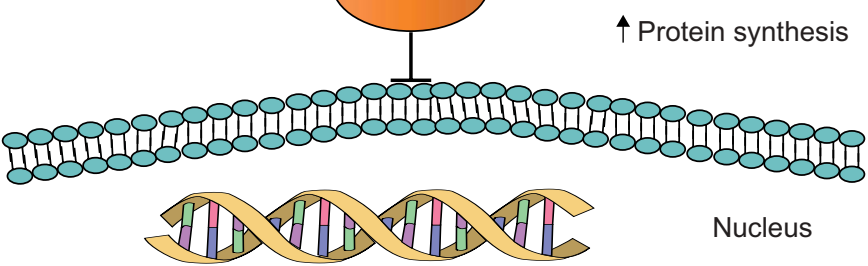

Nucleus

Atrophy related genes ( $\downarrow$ atrogin-1, MuRF-1)

(E3 ligases in the ubiquitin-proteasome pathway)

$$
\downarrow \text { Protein degradation }
$$

b)

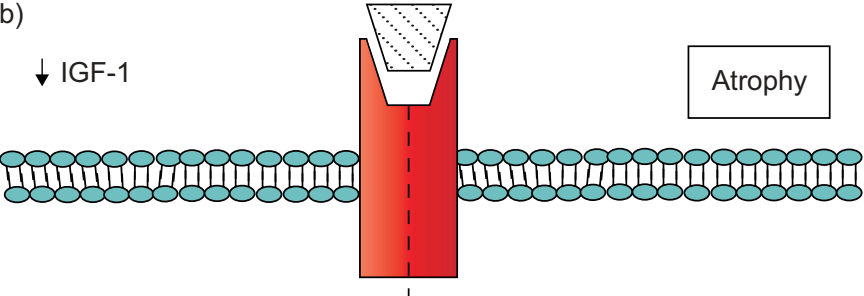

Cytosol

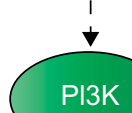

Deactivation
mTOR

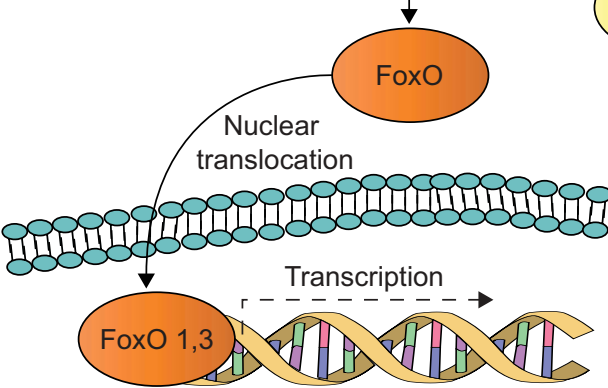

Atrophy related genes ( $\uparrow$ atrogin-1, MuRF-1)

$\uparrow$ Protein degradation

FIGURE 1. Insulin-like growth factor (IGF)-I mediates many of the actions of growth hormone. IGF-I can originate from the liver (endocrine function of IGF-I) or locally (autocrine/paracrine function). a) IGF-I stimulates muscle protein synthesis and hypertrophy via the phosphatidylinositol 3-kinase (PI3K)-Akt pathway. (PI3K can also be activated by insulin and other extracellular signals [13].) Akt, activated by Pl3K-induced phosphorylation, stimulates several hypertrophic pathways including glycogen synthase kinase- $3^{\beta}$ (not shown) and the mammalian target of rapamycin (mTOR). mTOR itself can promote protein synthesis through activation of 70-kD ribosomal S6 protein kinase and by inhibiting eukaryotic translation initiation factor 4 E binding protein-1 (not shown) [14]. IGF-I also reduces net protein breakdown by inactivation of the forkhead box class $O$ (FoxO) transcription factors 1, 3 through Akt-mediated phosphorylation. Inactivation of FoxO factors 1, 3 decreases the expression of atrophy-related genes or "atrogenes" including atrogin-1 (also known as muscle atrophy F-box or MaF-bx) and muscle ring finger 1 (MuRF-1) both E3-ubiquitin ligases in the ubiquitin-proteasome proteolytic pathway [15] and other atrophy-related genes such as poly-ubiquitin, metallothionein, and cathepsin-L (not shown) [16]. In addition to its anabolic and anticatabolic effects, the IGF-I activation of Akt and inhibition of FoxO increases the resistance of many cells to apoptosis (programmed cell death) [17]. b) When IGF-I levels are low, as during administration of glucocorticoids, the protein synthesis triggered by the IGF-I/PI3K/Akt pathway is reduced and protein degradation is increased. Not shown is a second IGF-I intracellular signaling pathway that potentiates proliferation of myoblasts and satellite cells through the activation the mitogen-activated protein kinase cascade [17] 
mRNA expression in the liver and limb muscles but not in the diaphragm [11]. Nutritional supplements can increase levels of IGF-I [27].

\section{Glucocorticoids}

Steroid myopathy results, at least in part, from a perturbation of the GH/IGF-I system [28, 29]. Steroid myopathy can affect respiratory and limb muscles and produce a wide range of manifestations [15]. On one end of the spectrum, usually associated with chronic moderate doses of glucocorticoids, is a mild-to-moderate weakness, mild myosin loss, and atrophy of type II fibres and less-so of type I fibres (table 1). On the opposite end, usually associated with acute administration of large doses of glucocorticoids in critically ill patients, is severe paresis, sarcomeric disarray, profound atrophy and acute myonecrosis [15].

Studies suggest that glucocorticoid-induced depression of the GH/IGF-I system contributes to the development of steroid myopathy [11, 16, 30-32] (fig. 1). In healthy subjects, the combination of prednisone $\left(0.8 \mathrm{mg} \cdot \mathrm{kg}^{-1} \cdot \mathrm{day}^{-1}\right)$ plus recombinant human GH for 7 days increased protein synthesis but did not decrease proteolysis [33]. Whether administration of recombinant human $\mathrm{GH}$ prevents myopathy in patients is unknown. In laboratory animals, administration of recombinant human GH may [34] or may not [35] attenuate steroid myopathy. In contrast to the conflicting effects of the administration of recombinant human GH on myopathy, administration of IGF-I in laboratory animals with [32] or without emphysema [36] attenuates [36] or totally prevents [32] steroid myopathy.

\section{Hypoxaemia}

In patients with COPD and moderate-to-severe hypoxaemia, muscle wasting is associated with depressed protein synthesis [37]. Whether or not the depressed protein synthesis is caused by impairment in the somatotropic axis is controversial. SCALVINI et al. [18] recorded GH levels in 17 stable patients with COPD (eight of whom were hypoxaemic). In nonhypoxaemic patients, GH levels were 3-fold greater than GH levels recorded in healthy subjects. In hypoxaemic patients, $\mathrm{GH}$ levels were 5-fold greater than GH levels recorded in healthy subjects. The investigators speculated that increased levels of $\mathrm{GH}$ in COPD might reflect a nonspecific response of the body to stress. Such upregulation of GH could play a role in pulmonary vasculature remodelling and right-sided hypertrophy of patients with pulmonary hypertension [18]. That hypoxaemia can increase GH levels is supported by a recent study of BENSO et al. [38], which recorded an increase in GH concentration, as well as an increase of total IGF-I, in athletes after 7 weeks of high-altitude exposure to hypoxia. Despite higher levels of IGF-I, hypoxia was associated with a decrease in body weight [38]. In contrast to the data in healthy subjects, hypoxaemic children with cyanotic congenital heart diseases have depressed IGF-I [39]. Depressed IGF-I is independent from nutritional status [39]. In animal models, IGF-I administration only partially reverses the catabolic effects of hypoxaemia [40].

\section{Hypercapnia}

In nine patients with COPD who had hypoxaemia, hypercapnia and peripheral oedema, GH concentrations were 11-fold greater than normal [41]. In that study, it was not possible to dissect the potential effects of hypoxaemia $[18,38]$ from those of hypercapnia on the circulating levels of GH. An independent effect of hypercapnia on GH was suggested by the observation that, acute normoxic hypercapnia in mechanically ventilated patients increased levels of GH [19].

\section{Inflammatory cytokines}

Circulating and local levels of tumour necrosis factor (TNF)- $\alpha$ and other inflammatory cytokines can be increased in patients with COPD [42]. In cultured myoblasts, TNF- $\alpha$ at low concentrations induces a state of IGF-I receptor resistance [43]. Such resistance is responsible for inhibition of protein synthesis stimulated by IGF-I [43] and IGF-I-stimulated expression of myogenin, a key myogenic transcription factor [43].

\section{COPD and depression of the somatotropic axis: prevalence}

Limited information is available on the interaction between COPD and the somatotropic axis. In 87 patients with COPD enrolled in a rehabilitation program, CASABURI et al. [44] reported that levels of IGF-I were about half the values recorded in healthy subjects. In a follow-up study, they reported that levels of IGF-I were low in 47 men with COPD and low testosterone (mean total testosterone concentration $320 \mathrm{ng} \cdot \mathrm{dL}^{-1}$ ) [45]. As in the studies by CASABURI and colleagues [44, 45], other investigators have reported a high prevalence of decreased IFG-I in stable patients with COPD $[46,47]$ and in patients experiencing an exacerbation [47]. The high prevalence of decreased IGF-I in several investigations [44-48] raises the possibility that a depression of the somatotropic axis may contribute to the decreased muscle mass in some patients with COPD.

In contrast to the preceding studies [44-48], other investigators $[14,49]$ found that IGF-I in patients with COPD and muscle atrophy is equivalent to that in healthy subjects. These contrasting results may be reconciled by the variable concentration of ghrelin, a novel GH-releasing peptide synthesised by the stomach, anterior pituitary and hypothalamus [22]. Levels of ghrelin can be higher in underweight patients with COPD than in normal-weight patients with COPD and healthy volunteers [46]. Decreased levels of IGF-I in patients with COPD and muscle atrophy [14, 49], despite higher levels of ghrelin [46], might indicate that the somatotropic axis in these underweight patients has developed resistance to the biological functions of ghrelin. The aforementioned studies [14, 49] are limited by the failure to determine whether the local expression and function of IGF-I, and its downstream pathways (fig. 1), are affected by COPD.

The pathways downstream of IGF-I have been recently assessed by DOUCET et al. [14]. Patients with COPD and muscle atrophy had greater expression of some components of the catabolic pathways in the quadriceps than healthy subjects, including increased levels of atrogin-1 and muscle ring finger protein (MuRF)1 mRNA and of forkhead box class $\mathrm{O}$ protein (FoxO)-1 (fig. 1). What role the IGF-I system has in determining muscle atrophy is difficult to assess. First, serum levels of IGF-I in patients with COPD and muscle atrophy were similar to the corresponding levels in healthy subjects [14]. Yet, muscle IGF-I mRNA expression in hospitalised and in stable patients with COPD measured by other investigators [10] was lower than in healthy elderly subjects. Secondly, compared with 


\begin{tabular}{|c|c|c|c|c|}
\hline \multirow[t]{2}{*}{ TABLE 1} & tics of & differen & types of & nuscle \\
\hline & Type I & Type Ila & Type IIx & Type Ilb \\
\hline \multicolumn{5}{|l|}{ Contractile properties } \\
\hline Velocity of shortening & + & ++ & +r+ & ++++ \\
\hline Tetanic force & + & + & ++ & + \\
\hline Endurance & +r++ & +++ & ++ & + \\
\hline Work efficiency ${ }^{\#}$ & +++ & + & ++ & + \\
\hline \multicolumn{5}{|l|}{ Histochemistry } \\
\hline $\begin{array}{l}\text { Mitochondrial volume } \\
\text { density }\end{array}$ & +++ & +r+ & ++ & + \\
\hline ATP consumption rate & + & ++ & +++ & ++++ \\
\hline Oxidative enzymes & +++ & +++ & ++ & + \\
\hline Glycolytic enzymes & + & ++ & +r+ & ++r+ \\
\hline Glycogen & + & ++ & + & +++ \\
\hline Capillary supply & +++ & ++ & + & + \\
\hline Diameter & + & + & + & +++ \\
\hline
\end{tabular}

ATP: Adenosine triphosphate. ${ }^{\#}$ : amount of work performed per unit of ATP consumed. + : relative expression of a given characteristic of the muscle fibre. A single myosin heavy chain isoform is typically expressed within an adult skeletal muscle fibre. Fibres classified as type I, Ila, IIx and IIb express myosin heavy chain isoform I (or slow), Ila, IIx and IIb, respectively. Type IIx fibres have been reported in peripheral muscles of humans and animals and in the diaphragm of animals. Type IIx fibres have not been reported in the human diaphragm. More than one myosin heavy chain isoform is expressed in a few fibres $(\sim 14 \%$ of adult rat diaphragm co-expresses myosin heavy chain isoforms $\mathrm{Ilb}$ and $\mathrm{IIx}$ and $<1 \%$ co-expresses myosin heavy chain isoforms I and IIa). While the velocity of muscle contraction depends primarily on the myosin heavy chain isoform, the velocity of muscle relaxation is mainly determined by troponin $\mathrm{C}$ calcium binding and release and by calcium re-uptake by the sarco-endoplasmic reticulum calcium-adenosine thriphosphatase (SERCA). Several SERCA isoenzymes have been identified: SERCA 1 is expressed in type II fibres (fast calcium re-uptake) and SERCA 2a is expressed in type I fibres (slow calcium reuptake). The density of pumping sites largely accounts for different rates of calcium uptake in fast- and slow-twitch muscle fibres. Despite this separation of tasks, velocity of contraction and velocity of relaxation tend to parallel each other; type II fibres contract and relax with a greater velocity than type I fibres. Slower velocity of relaxation allows fusion of repetitive twitches at lower frequencies of stimulation compared with fast relaxations. Impairment of SERCA activity has been implicated in the development of fatigue and in disease states, including heart failure and corticosteroid myopathy. Reproduced from [15] with permission from the publisher

patients with COPD who have muscle atrophy, patients with preserved muscle mass showed similar activation of the atrophying factors and increased expression of some components of the anabolic pathways. It is possible that patients with muscle atrophy are not able to respond to the upregulated hypertrophy signalling pathways [14]. Possible mechanisms include ageing and dysfunction of translational efficiency or capacity [14]. This mechanism is also supported by the observation that levels of GH are higher in cachectic patients with COPD than in noncachectic patients [50]. The latter finding suggests that acquired $\mathrm{GH}$ resistance contributes to the cachexia [50].
Upregulation of the IGF-I system within the fibres of the diaphragm has been reported within 4 days after lung-volume reduction surgery in hamsters [51]. This upregulation is likely to be an anabolic response to passive stretch of the diaphragm and ultrastructural sarcomeric injury [51].

\section{COPD and depression of the somatotropic axis: functional consequences}

Decreased muscle mass

In patients with COPD, decreased muscle mass reduces respiratory muscle function, limb muscle function, exercise capacity and life expectancy [15]. As already stated, whether a depression of the somatotropic axis contributes to decreased muscle mass in COPD, however, is unclear, and administration of recombinant human GH has produced mixed results.

In seven patients with COPD and ideal body weight (Metropolitan height-weight tables for adults) of $<90 \%$, 3 weeks of recombinant GH increased weight, improved nitrogen balance and maximal inspiratory pressure [52]. These results contrast with the negative results of BURDET et al. [48], the only randomised-controlled trial in malnourished patients with COPD. Several factors may explain the negative results of BURDET et al. [48]: first, redistribution of protein toward central organs rather than toward the muscles [48]; secondly, small dose and short duration of therapy (3 weeks) [48]; thirdly, uncoupling of Akt (activated by IGF-I) and the downstream anabolic and catabolic pathways (fig. 1) [14]. Lack of beneficial effect of recombinant GH on muscle function has also been reported in patients requiring prolonged mechanical ventilation, half of whom had COPD [53]; recombinant GH can increase mortality of critically ill patients [54].

In the study of BURDET et al. [48], maximal power output and oxygen consumption at the conclusion of a symptom-limited exercise test were not affected by recombinant GH administration. The response to six-minute walk was decreased in the treated patients [48]. A potential mechanism for this decrease in submaximal tests is an increase in oxygen consumption and carbon dioxide production induced by GH [48]. This possibility, however, is not supported by data recorded in young patients with COPD caused by cystic fibrosis in whom recombinant $\mathrm{GH}$ administration produced a significant increase in exercise capacity $[55,56]$.

In adults, chronic recombinant GH therapy can be associated with significant side effects including arthralgia, carpal tunnel syndrome, oedema and abnormal glucose tolerance [57, 58]. The potential risk of development and progression of common cancers including colon, breast and prostate cancers with chronic use of IGF-I [59] raises important questions on selection criteria, monitoring and safety of any study of recombinant GH/IGF-I supplementation in COPD.

Recently, NAGAYA et al. [60] investigated a novel pharmacological strategy to modulate the somatotropic axis in patients with severe COPD. Administration of ghrelin for 3 weeks produced increased appetite, increased circulating $\mathrm{GH}$, increased peripheral and respiratory muscle strength, increased six-minute walking distance and decreased plasma norepinephrine; levels of IGF-I were unaffected by ghrelin. These positive findings [60] must be interpreted with caution because the study was open labelled and lacked a control arm. 
In patients with severe COPD, nonpharmacological upregulation of anabolic signals in the vastus lateralis muscle, including IGF-I and MyoD proteins and mRNA of IGF-I, and its loadsensitive splice variant (mechanogrowth factor), can be induced by pulmonary rehabilitation [61]. This favourable response is associated with a reduction in the proportion of type IIb muscle fibres (table 1), increases in the mean crosssectional area of all fibre types and improved peak exercise work rate [61]. The anabolic effect occurred despite the fact that rehabilitation did not decrease plasma levels of inflammatory mediators $[61,62]$ and it did not decrease mRNA expression of TNF- $\alpha[61,62]$ and interleukin (IL)- 6 in the muscle [61].

\section{COPD and depression of the somatotropic axis: treatment} Despite the plausibility of linking derangements of the somatotropic axis and decreased muscle mass in COPD, it is premature to recommend the use of recombinant GH, IGF-I or ghrelin in patients with COPD and decreased muscle mass.

\section{COPD AND GONADAL AXIS}

In men and women, the gonadal axis is a complex network of hormones that includes testosterone, an important anabolic hormone [63]. In men, the main production site of androgens is the testicle [63]; in women, the adrenals and the ovaries [64]. Secretion is stimulated by luteinising hormone (LH), one of the pituitary gonadotropins [65]. Under physiological conditions, about $44 \%$ of circulating testosterone is strongly bound to the sex hormone binding globulin; $54 \%$ is weakly bound to albumin and other lower affinity, high-capacity binding sites, such as $\alpha_{1}$ acid glycoprotein and transcortin [66]. About $2 \%$ of circulating testosterone is nonprotein bound, i.e. free testosterone. Together, weakly bound testosterone and free testosterone are referred to as "bioavailable testosterone" [66]. Women have much lower levels of circulating testosterone than men. In both men and women, testosterone is responsible for libido, sexual hair and anabolic functions that affect muscle and bone [64,67].

In patients with COPD, testosterone supplementation can increase leg muscle mass [45] and vastus lateralis mRNA for slow / $\beta$-myosin heavy chain [68]. These anabolic responses are accompanied by increases in vastus lateralis IFG-I protein and myogenin mRNA [68]. In these patients, circulating levels of IGF-I [45] and intramuscular expression of MyoD mRNA and myostatin mRNA [68] are not affected by testosterone supplementation. Taken together, these data suggest that androgens produce an enhanced local anabolic milieu, driven in large part by the muscle's IGF system. Increased size of motor neurons [69] is an additional mechanism through which androgens may exert their anabolic action.

The concentration of serum testosterone [70, 71] and other androgens, such as the adrenal steroid dehydroepiandrosterone (DHEA), a testosterone precursor [72], decline in middleaged and elderly men. When excessive, this decline may contribute to various signs and symptoms, including decreased energy level, libido, bone density and muscle mass and, possibly, reductions in cognitive function and memory [73]. This constellation of signs and symptoms has been termed late-onset hypogonadism, symptomatic late-onset hypogonadism, androgen deficiency in the ageing male or andropause
[67]. The observation that many men with COPD fit the profile of late-onset hypogonadism [74-76] has spurred a flurry of research on the incidence [76-78], functional impact [49, 76, 78] and possible treatment [45] of this abnormality.

As in men, levels of testosterone and of other androgens, such as DHEA, decline in women with ageing [24]. This process starts before, and continues after, the menopause [24]. Little is known about the impact of declining levels of testosterone and other androgens in women with COPD. Accordingly, most of our discussion will focus on late-onset hypogonadism in men with COPD.

\section{COPD and late-onset hypogonadism: risk factors}

Several risk factors that may decrease testosterone in patients with COPD have been reported. These include ageing, chronic disease, hypoxaemia, hypercapnia, smoking, administration of glucocorticoids, systemic inflammation and obesity.

\section{Ageing}

Purported mechanisms by which old age causes hypogonadism in men include decreased responsiveness of the testes to human chorionic gonadotropin (which acts as LH), increased testosterone feedback at the hypothalamic-pituitary level, decreased responsiveness of the pituitary to gonadotropin releasing hormone, and asynchronous (chaotic) release of gonadotropin releasing hormone from the hypothalamus [79]. In men, sex hormone binding globulin increases with age [23] and reduces the biological availability of testosterone [23].

The mechanisms responsible for age-related decrease in testosterone in women include decreased adrenal production of DHEA and DHEAS [80], decreased ovarian production of androgens [80] and increased specific activity of aromatase in the adipose tissue [81].

\section{Chronic illness}

Chronic illnesses, including diabetes, cardiovascular disease and hypertension, have been associated with a decline in serum testosterone [82]. An important contributor to this decline is a decrease in LH (hypogonadotrophic hypogonadism) [82], the most common presentation of late-onset hypogonadism in men with COPD $[45,76]$. Whether COPD is a "chronic illness" that can cause, by itself, hypogonadism is controversial considering that among ambulatory men with COPD severity of lung disease does not predict the hormonal abnormality [76, 78]. Also, the number of comorbid conditions in hypogonadal and eugonadal men with COPD is similar [78]

While the prevalence of hypogonadism seems to be unaffected by severity of COPD when patients are in a stable clinical condition [76, 78], acute exacerbations [83] and, possibly, the need for prolonged mechanical ventilation [84], can (further) decrease testosterone.

\section{Hypoxaemia/Hypercapnia}

In 1980, SEMPLE et al. [85] assessed serum levels of testosterone and gas exchange in 22 men with COPD. When the partial pressure of arterial oxygen $\left(\mathrm{Pa}_{\mathrm{a}} \mathrm{O}_{2}\right)$ dropped below $55 \mathrm{mmHg}$, there was a strong correlation between the degree of hypoxia and the degree of testosterone reduction. Lack of association between testosterone and hypoxia (when $\mathrm{Pa}_{\mathrm{a}_{2}}$ is $>55 \mathrm{mmHg}$ ) 
has been confirmed by more recent studies [49, 76, 78]. SEMPLE et al. [85] also reported a correlation between the degree of hypercapnia and testosterone.

\section{Smoking}

In men, both testosterone and sex hormone-binding globulin are greater in smokers than in nonsmokers, yet, levels of bioavailable testosterone are similar [86]. These results suggest that smoking modulates total testosterone through changes in the concentration of sex hormone-binding globulin but has no significant impact on the biologically active fraction of the hormone.

\section{Glucocorticoids}

The effect of glucocorticoids on testosterone concentration is controversial [49, 76-78]. In 36 men with COPD, 16 of whom were taking oral glucocorticoids, KAMISCHKE et al. [77] found that free testosterone was inversely related to glucocorticoid dosage. Mechanisms that may explain the decrease in levels of testosterone include a reduction in gonadotropin releasing hormone, decrease in adrenal precursors and reduction of testosterone biosynthesis [77]. In addition, glucocorticoids may compete with testosterone for the same receptor sites in the peripheral tissues [87]. Despite these results [77], three groups of investigators have more recently reported no correlation between testosterone and glucocorticoid therapy in men with COPD $[49,76,78]$.

\section{Systemic inflammation}

In laboratory animals [88] and healthy men [89], TNF- $\alpha$ can lead to decreased testosterone. Mechanisms through which TNF- $\alpha$ and other inflammatory cytokines, such as IL-1 and IL-6, could decrease testosterone include increased expression of aromatase, the enzyme that irreversibly converts testosterone to oestradiol (via the testosterone-oestradiol shunt) [90], a reduction in gonadotropin releasing hormone [65] and a cytokine-mediated testicular defect [88, 91]. Despite the biological plausibility, a recent investigation in more than 100 men with COPD [83] suggested that the increased levels of inflammatory cytokines in patients with stable COPD were insufficient to decrease testosterone concentrations.

\section{Obesity}

Body mass index of men with COPD and late-onset hypogonadism is greater than that of eugonadal men with COPD with similar age and severity of lung disease [76]. Increased body mass index could result from a positive feedback between obesity and hypogonadism. Hypogonadism is associated with a preferential deposition of adipose tissue in the abdomen [92]. A state of leptin resistance may contribute to this increased adipose deposition [93]; in men, levels of leptin have been reported to be inversely related to testosterone [94]. A second mechanism is a decrease in serum concentrations of ghrelin [95] resulting in less fat utilisation [96]. Irrespective of the mechanism, greater adipose tissue accumulation increases aromatase activity and, thus, the conversion of testosterone to oestradiol (testosterone-estradiol shunt) [90]. Such an upregulation could produce a vicious cycle where depression of testosterone concentration causes deposition of abdominal fat that, in turn, worsens the hypogonadal state [97].

\section{COPD and late-onset hypogonadism: prevalence}

LAGHI et al. [76] tested 101 men with stable COPD for late-onset hypogonadism. Late-onset hypogonadism was present in $38 \%$ of the men. This value falls between the prevalence of $69 \%$ reported by KAMISCHKE et al. [77] and 22\% reported DEBIGARE et al. [49].

The $47 \%$ difference in the prevalence of hypogonadism between the studies of KAMISCHKE et al. [77] and DEBIGARE et al. [49] cannot be ascribed to age or severity of COPD. It may be related to patient selection: $84 \%$ of the patients in the first study had concurrent chronic diseases [77], whereas patients with chronic diseases were excluded in the second study [49]. A difference in comorbidities can explain only $15 \%$ of the $47 \%$ difference [49]. Sample size is a more likely explanation. When data from the two investigations [49, 77] are combined, 35 $(43 \%)$ of 84 patients exhibit hypogonadism; similar to that in the study of LAGHI et al. [76].

VAN VLIET et al. [78] reported a prevalence of late-onset hypogonadism in $51 \%$ of 78 men with COPD and $26 \%$ of 21 age-matched controls. These results do not necessary mean that late-onset hypogonadism is more prevalent in men with COPD than in the general population. The prevalence of hypogonadism in the small control group [78] was much lower than the $34-40 \%$ prevalence of hypogonadism for subjects in their $60 \mathrm{~s}$ and the near $70 \%$ prevalence for subjects in their $70 \mathrm{~s}$, reported in large population studies [23, 70]. Levels of testosterone did not correlate with severity of airway obstruction $[76,78]$ or with a $\mathrm{Pa}, \mathrm{O}_{2}>55 \mathrm{mmHg}$ or glucocorticoid therapy $[49,76,78]$.

\section{COPD and late-onset hypogonadism: functional consequences}

Sexual function

In a study of 36 men with COPD, 25 of whom were hypogonadal, the prevalence of sexual difficulties was not associated with the level of free testosterone [77].

\section{Quality of life}

COPD [98-100] and late-onset hypogonadism [101] can decrease quality of life. To determine whether the occurrence of late-onset hypogonadism had an additive effect on reduced quality of life in COPD, LAGHI et al. [76] compared the results of the St George's Respiratory Questionnaire (SGRQ), a respiratory-specific questionnaire, and of the Veterans Short Form (SF)-36 Health Survey, a general health questionnaire, in 38 men with COPD and late-onset hypogonadism and 63 eugonadal men with similar severity of airway obstruction [76]. The questionnaire scores were similar in the two patient groups. Free testosterone was not associated with the perceived impact of COPD on health and well being [76].

Women with COPD report worse health-related quality of life than men [102]. Whether menopause and hormone supplementation in women with COPD could affect the healthrelated quality of life is untested.

\section{Depression}

Decreased testosterone levels [103, 104] and COPD [105] have been associated with depressed mood. Yet, the SGRQ impact score [106] and the SF-36 mental health domain [107], which 
are affected the presence of depression are equivalent in eugonadal and hypogonadal men with COPD [76].

\section{Respiratory muscles}

Recently, LAGHI et al. [108] reported that diaphragmatic contractility was similar in hypogonadal and eugonadal men with COPD (fig. 2). When performing a progressive inspiratory threshold loading protocol, hypogonadal and eugonadal patients had similar respiratory muscle endurance times, perceived inspiratory effort and perceived air hunger [108]. Neither group of patients developed diaphragmatic fatigue after loading (fig. 2). The lack of fatigue was similar to its absence after failed weaning from mechanical ventilation [109] and under more extreme conditions in laboratory animals [110].

The equivalent performance of the respiratory muscles in hypogonadal and eugonadal men [108] is consistent with the observations of CASABURI et al. [45], who found that inspiratory muscle strength was not altered by the administration of testosterone enanthate to patients with COPD who had variable serum testosterone levels.

Several mechanisms may protect the respiratory muscles against the deleterious effects of low testosterone levels. First, a conditioning effect of the increased inspiratory load [111] may counterbalance the catabolic effects [112, 113]. Secondly, in the investigation of LAGHI et al. [108], most patients were not underweight. Thirdly, respiratory muscles may be less sensitive to testosterone (and lack thereof) than the limb muscles considering that administration of massive doses of testosterone $\left(20 \mathrm{mg} \cdot \mathrm{kg}^{-1} \cdot \mathrm{day}^{-1}\right.$ for 14 days) to rabbits did not produce increased diaphragmatic strength or endurance [110].

\section{Limb muscles}

It is unclear whether late-onset hypogonadism in men with COPD affects limb muscle strength and endurance. In 78 men with COPD, VAN VLIET et al. [78] recorded a correlation

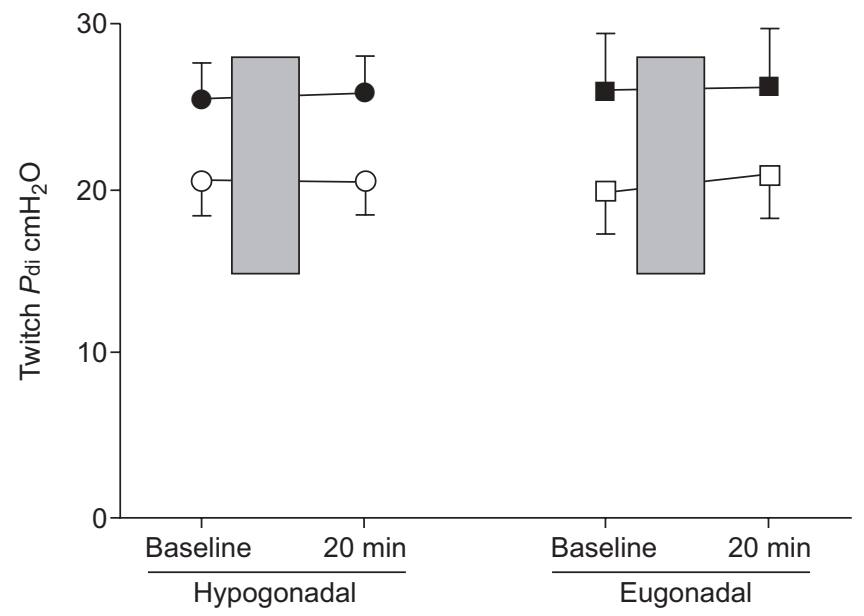

FIGURE 2. Potentiated $(\bullet, \mathbf{\square})$ and nonpotentiated $(\bigcirc, \square)$ transdiaphragmatic twitch pressure (twitch $P_{\text {di) }}$ in 10 hypogonadal $(\bullet, \bigcirc)$ and 10 eugonadal $(\boldsymbol{\square}, \square)$ men with COPD recorded before (baseline) and 20 min after conclusion of inspiratory threshold loading to task-failure. Potentiated and nonpotentiated twitch $P$ di values were not affected by hormonal status or by threshold loading. Date are presented as mean $\pm S E$. Reproduced and modified from [108] with permission from the publisher. between quadriceps strength and testosterone concentrations. Conversely, LAGHI et al. [108] recorded no difference in quadriceps strength (and endurance) between hypogonadal and eugonadal men with COPD. This equivalent limb muscle performance in the two patients groups is in line with the observation that testosterone has no effect on leg-muscle endurance when administrated at physiological doses in otherwise healthy hypogonadal men [114] or in healthy eugonadal men receiving a long-acting gonadotropin-releasing hormone agonist [115]. Likewise, the equivalent limb-muscle performance in the two groups is consistent with the observation that physiological doses of testosterone had no effect on leg-muscle strength in some hypogonadal men [116118]. Similarly, when BHASIN et al. [119] administered a longacting gonadotropin-releasing hormone agonist to induce hypogonadism in elderly men and then supplemented the men with sub-therapeutic doses of testosterone enanthate, they recorded no difference in fat free mass or muscle strength. When they doubled the circulatory levels of total and free testosterone using higher doses of testosterone enanthate, the increases in fat free mass and strength were within the noise of the measurement. They, however, reported a $17 \%$ increase in quadriceps strength (and endurance) when administering $100 \mathrm{mg} \cdot$ week $^{-1}$ of testosterone enanthate for 10 weeks in men with COPD who had variable testosterone levels [45]. It is not known why low testosterone should cause a decrease in strength in some studies and not in others, nor whether the statistical differences in quadriceps strength, when present, are clinically important. The same investigators reported preliminary results on testosterone supplementation (12.5 and $25 \mathrm{mg}$ testosterone enanthate weekly for 10 weeks) in women with COPD [120]. Only modest changes in body composition and strength without evidence of virilisation were observed.

\section{Exercise capacity}

Exercise capacity in men with COPD with and without lateonset hypogonadism has been found to be equivalent [76, 78, 108]. During cycle exercise to exhaustion, exercise performance, gas exchange and respiratory muscle recruitment (estimated by oesophageal and gastric pressure swings during tidal breathing) were similar in both groups [108]. Equivalent exercise capacity has been recorded even when quadriceps strength among hypogonadal patients with COPD was less than in eugonadal patients with COPD [78].

The similar exercise performance in patients with COPD with or without late-onset hypogonadism $[76,78,108]$ is consistent with the observation that administration of anabolic steroids to unselected patients with COPD [121, 122] or testosterone enanthate to men with COPD and variable testosterone levels [45] produced no improvement in whole body exercise capacity.

\section{Risk for cardiovascular disease}

Several case-control studies suggest an association between low testosterone levels and excess cardiovascular risk in men [123-125], while the opposite may be true in women [126]. It is not known whether late-onset hypogonadism has an additive effect on the already increased risk of cardiovascular disease associated with COPD [127-131]. 


\section{Bone density}

Reduced bone mineral density is common in COPD [74]. Reduced bone mineral density has not been associated with low testosterone levels in two studies [132, 133], possibly because the risk of osteoporosis is already so high in COPD that the additional effect of late-onset hypogonadism does not further affect bone mineral density.

\section{COPD and late-onset hypogonadism: therapy}

If patients are deficient in a hormone, it might seem selfevident to replenish normal levels. Before recommending hormone supplementation, however, it is critical to weigh potential risks and benefits. Stated differently, does it matter if a man with COPD develops late-onset hypogonadism? The question entails whether clinically important functional differences between hypogonadal and eugonadal patients do exist, which, in turn, could have important therapeutic implications. For some clinical aspects, the accumulating evidence suggests that men with COPD and late-onset hypogonadism are not different from their nonhypogonadal counterparts. Therefore, if testosterone is administered, it would be unclear what should be the therapeutic effects to monitor.

The caution about whether to advocate testosterone replacement in men with late-onset hypogonadism and COPD needs to reflect the ongoing controversy regarding indications for testosterone replacement in older men in general [67, 73, 134]. Long-term testosterone supplementation can be associated with side effects, including increase in haematocrit, sleep apnoea, prostatic hypertrophy (fig. 3) [67, 73]. Long-term effects of testosterone administration on the risk of atherosclerotic heart disease and prostate cancer remain unknown $[67,73]$. More than 6,000 elderly hypogonadal men, randomly assigned to receive testosterone or placebo for 6 years, would be necessary to determine whether testosterone treatment increases the risk of prostate cancer by $30 \%$ [73]. The Institute of Medicine (Washington DC, USA) recently concluded that, unless more convincing studies are published, there is currently insufficient evidence to support testosterone therapy in older men [135].

\section{COPD AND ADRENAL AXIS}

The adrenal glands produce a vast array of hormones with protean metabolic effects; among these are cortisol, DHEA and its metabolite, DHEAS, the most abundant steroid present in the blood [49]. The action of DHEAS at the tissue level is both direct, through specific binding sites of the hormone in peripheral tissues [136], and indirect. The indirect action occurs as a result of the conversion DHEAS to androstenedione or androstenediol, and finally to testosterone [137]. Reduced levels of DHEA and DHEAS and high cortisol/DHEA or cortisol/DHEAS ratios are thought to create an imbalance between protein synthesis and degradation favouring catabolism over anabolism [49].

In contrast to the anabolic properties of DHEA and DHEAS, cortisol (when in excess) has catabolic properties [138]. Cortisol mobilises glucose, free fatty acids and amino acids from endogenous stores [138]. In addition, cortisol increases appetite and induces insulin resistance [138].

\section{COPD and imbalance of the adrenal axis: risk factors}

Ageing

Serum concentrations of DHEAS decrease with ageing [24, 72, 139], whereas concentrations of cortisol do not [71].

\section{Severity of COPD/hypoxaemia/hypercapnia}

Severe airway obstruction, hypoxaemia and hypercapnia have been associated with decreased serum levels of DHEAS [83] Whether severity of lung disease affects serum levels of cortisol is unclear $[18,41,140]$.

\section{COPD and imbalance of the adrenal axis: prevalence}

The limited available information suggests circulating levels of DHEAS are decreased in COPD [49, 83]. DEBIGARE et al. [49] found lower DHEAS levels in patients with COPD and decreased muscle mass than in those without decreased muscle mass or in control subjects. Similarly, KARADAG et al. [83] found lower DHEAS levels in patients with COPD than in controls. During acute exacerbations DHEAS levels decreased even further [83].

Whether cortisol levels are altered in patients with stable COPD is unclear [18, 41, 141, 142]. Systemic and possibly (highdose) inhaled corticosteroids increase the risk of adrenal insufficiency [143].

During acute exacerbations, levels of cortisol are increased in patients not treated with systemic corticosteroids [144]. In these patients, the cortisol response to adrenocorticotropic hormone (ACTH) is normal [144]. In contrast, patients treated with corticosteroids during an exacerbation have decreased circulating cortisol levels and commonly limited cortisol response to ACTH [145]. The limited response can last more than 3 weeks after corticosteroid withdrawal [145]. Neither glucocorticoid dose nor duration of treatment can be used to predict adrenal insufficiency [146].

\section{COPD and imbalance of the adrenal axis: functional consequences}

Decreased muscle mass/decreased muscle function

In men with severe COPD, the cortisol/DHEAS ratio was greater among patients with decreased muscle mass than among those without decreased muscle mass [49]. Nevertheless, administration of DHEA, for 2 years, to elderly men and women without COPD and reduced DHEAS levels had no effect on body composition, exercise capacity, muscle strength or quality of life [147].

\section{Osteoporosis}

Among women who, for the most part did not have COPD, lower DHEA levels were associated with decreased bone-mineral density [139]. Yet, when administered to elderly men and women without COPD, DHEA had minimal and inconsistent effects on bone-mineral density [147].

\section{COPD and imbalance of the adrenal axis: therapy}

In elderly patients without COPD, DHEA administration had no significant benefit [147].

\section{COPD AND DIABETES}

Insulin is an anabolic hormone that exerts its effects by binding to its cognate receptor [148]. Many cells throughout the body, 


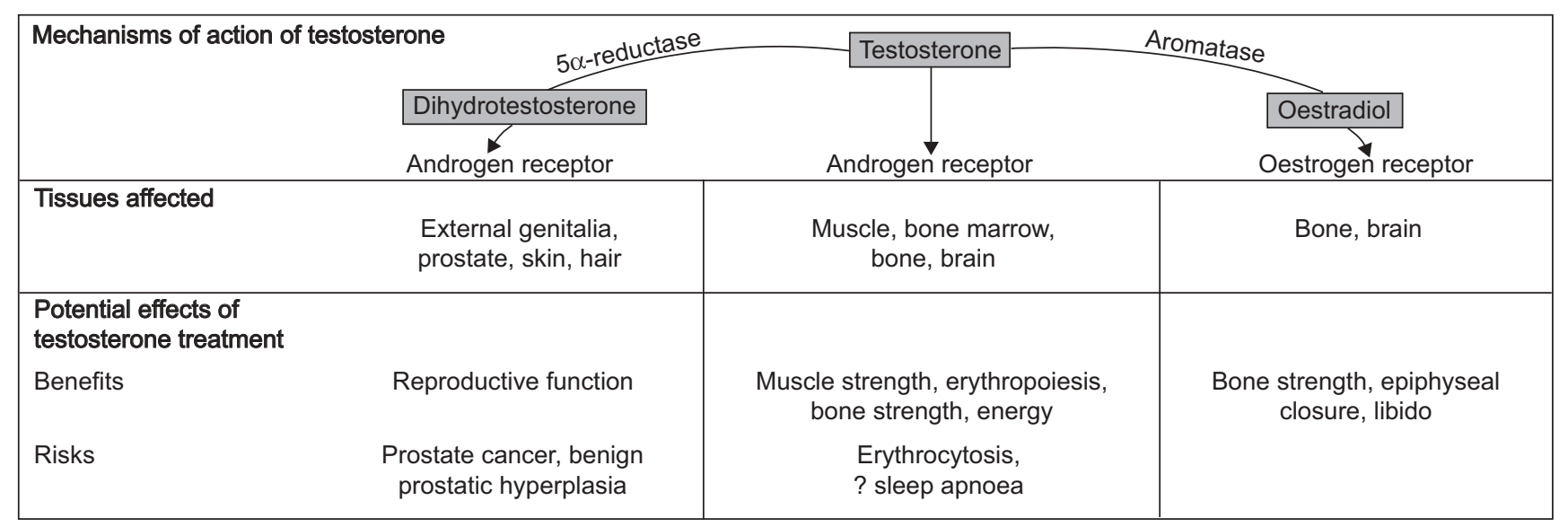

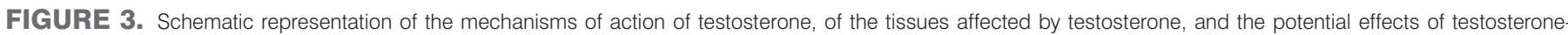

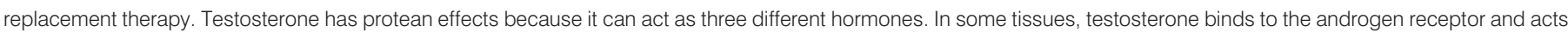

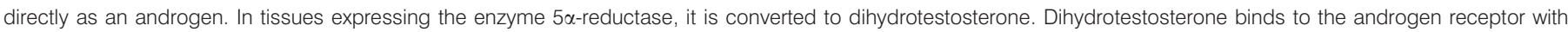

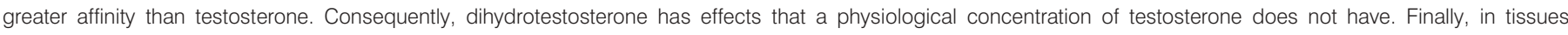

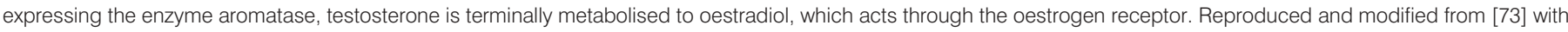
permission from the publisher.

including liver, lung, skeletal muscle, adipose tissue and vascular endothelial cells, express this transmembrane receptor $[149,150]$. When insulin binds to the receptor in myocytes, it activates the intrinsic tyrosine protein kinase activity [8]. The activated receptor phosphorylates the insulin receptor substrates 1 and 2, which, in turn, activate PI3K and, with it, the mTOR signal transduction pathway (fig. 1) [8]. Insulin is a mitogen and growth factor of airway smooth muscle cells and of bronchial and alveolar epithelial cells [149]. In vitro, insulin improves hypoxia-induced vasoconstriction and causes pulmonary artery vasodilation [149].

Diabetes mellitus can result from destruction of the pancreatic $\beta$ cells, which leads to absolute insulin deficiency (type 1) or, more often, from insulin resistance coupled with relative impairment in insulin secretion (type 2) [151]. Abnormalities of the insulin receptor and abnormalities downstream to the receptor contribute to insulin resistance in patients with type 2 diabetes [150].

\section{COPD and diabetes: prevalence/risk factors}

The prevalence of diabetes in patients with COPD is $10-14 \%$ [78, 152-154]. The relationship between impaired pulmonary function and increased risk of developing diabetes is controversial [131, 154-156]. Among almost 8,000 participants in the Framingham Heart Study [154] and the National Health and Nutrition Examination Survey [155], there was no association between COPD and the development of diabetes. In contrast to these studies, in which about half the participants were men, COPD was found to increase the risk of diabetes in the Nurses' Health Study (involving nearly 100,000 female nurses; multivariate relative risk $1.8,95 \%$ CI 1.1-2.8) [156]. Likewise, among more than 20,000 participants (56\% female) of the Atherosclerosis Risk in Communities Study (ARIC) and the Cardiovascular Health Study (CHS), the presence of moderateto-severe COPD was shown to increase the risk of diabetes (multivariate relative risk $1.5,95 \%$ CI 1.1-1.9) [131]. It is not possible to reconcile the contrasting results. The mechanisms through which COPD might induce type 2 diabetes include systemic inflammation, oxidative stress, smoking and administration of glucocorticoids.

\section{Smoking/systemic inflammation/oxidative stress}

Cigarette smoking can increase the risk of insulin resistance and diabetes by triggering systemic inflammation [154, 157] and oxidative stress [158]; both of which are common in COPD [154, 157-159]. In nonhypoxaemic nondiabetic patients with COPD, insulin resistance was linked to systemic inflammation (via IL-6) and body mass index [160].

\section{Glucocorticoids}

In elderly patients, administration of systemic glucocorticoids more than doubles the risk of developing diabetes [161]. Potential mechanisms include direct inhibition of insulin release, reduction in the hepatic levels of insulin receptor substrate-1 and PI3K, decrease in glucose uptake and increase in hepatic glucose production $[162,163]$.

Systemic and topical glucocorticoids are used in patients with COPD during exacerbations and as maintenance therapy. Systemic corticosteroids can interfere with glycaemic control $[161,164]$ and poor glycaemic control in patients hospitalised for COPD exacerbation has been associated with increased length of hospital stay and increased mortality [165]. Diabetes is a risk factor for mortality, even after hospital discharge for COPD exacerbations [166]. It is unclear whether short- [165] and long-term survival [166] following an acute COPD exacerbation can be improved by tight glycaemic control.

In contrast to systemic glucocorticoids, administration of inhaled glucocorticoids is probably safe in patients with COPD and diabetes [161, 167]. In 10 patients with type 2 diabetes and asthma or COPD, inhaled glucocorticoids for 6 weeks caused no change in glycosylated haemoglobin [167]. 


\section{COPD and diabetes: functional consequences}

In patients who do not necessarily have COPD, diabetes can negatively affect respiratory muscle function, pulmonary mechanics, gas exchange and respiratory drive. Patients with diabetes are also at increased risk of infections and cardiovascular complications.

\section{Respiratory muscles}

Patients with diabetes exhibit a $20 \%$ decrease in global inspiratory strength [168] and a 30-50\% decrease in diaphragmatic strength [168, 169]. Weakness might result from nonenzymatic glycosylation (glycation) of muscle fibres (fig. 4) [170, 171]. Rarely, diaphragmatic weakness results from diabetic neuropathy of the phrenic nerves $[172,173]$, which can occur despite the absence of peripheral neuropathy [173].

\section{Pulmonary mechanics/gas exchange}

Lung specimens in patients with diabetes demonstrate several abnormities that are reminiscent of those described in the glomeruli. These abnormities include intraseptal nodular fibrosis, microangiopathy, thickening of the basal laminae of pulmonary capillaries and loss of alveolar microvascular bed associated with increased extracellular matrix and connective tissue [149]. Thickening of the basal laminae of pulmonary capillaries and loss of alveolar microvascular bed [149] may contribute to increased work of breathing, decreased diffusing capacity [149] and dyspnoea in patients with diabetes [174].

\section{Respiratory drive}

The ventilatory response to hypercapnia is normal in diabetic patients without autonomic neuropathy, reduced in patients with parasympathetic neuropathy and increased in patients with combined parasympathetic and sympathetic neuropathy [175]. The differences have been attributed to proportional variation in cerebrovascular reactivity (velocity of blood flow in the middle cerebral artery) to hypercapnia [175]. Parasympathetic neuropathy, with secondary depression of vagal tone, may contribute to diminished bronchodilator

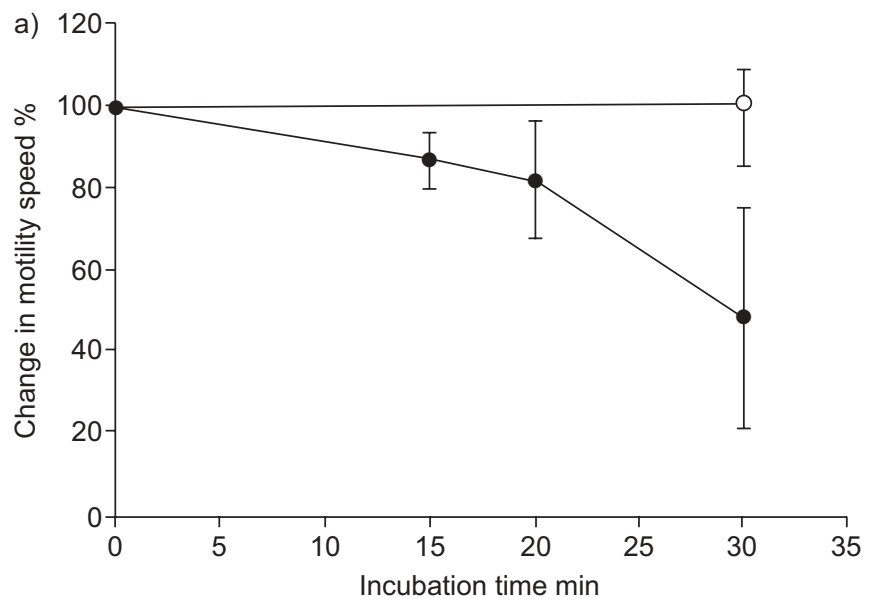

response to anticholinergic drugs in some patients with diabetes [149].

\section{Infections}

Diabetes increases the risk of lower respiratory tract infections [176]. In patients with COPD exacerbations requiring noninvasive ventilation, hyperglycaemia is associated with pulmonary infections and is an independent risk factor for failure of noninvasive ventilation [177]. In euglycaemic subjects with airway inflammation or in hyperglycaemic patients, glucose concentrations in airway secretions are increased [178] Mechanically ventilated patients with detectable glucose in bronchial aspirates have increased likelihood of pathogenic bacteria, particularly Staphlococcus aureus [179]. Airway glucose may promote bacterial growth or interfere with local immune defences [165].

\section{Osteoporosis}

Diabetes has been associated with higher bone mineral density in both women and men [180, 181]. The higher bone mineral density could result from the hyperinsulinaemia that precedes overt type 2 diabetes [181]. In turn, hyperinsulinaemia could exert an anabolic effect on bone tissue [181]. Hyperinsulinaemia has been reported in nondiabetic patients with COPD [160]. Despite a higher bone mineral density, patients display an increased risk of fractures, mainly attributable to the increased risk of falling [182].

\section{COPD and diabetes: therapy}

The goal of diabetic care is to achieve glucose levels close to normal without inducing significant hypoglycaemia [183] With the exception of inhaled insulin [184], strategies to reach this goal in COPD should be the same as for diabetic patients without COPD [183, 185, 186]. Detailed reviews of this topic are available elsewhere $[183,185,186]$.

In 2006, US and European Drug Agencies (the US Food and Drug Agency and the European Medical Association) approved inhaled insulin for clinical use in nonsmoking adults with type

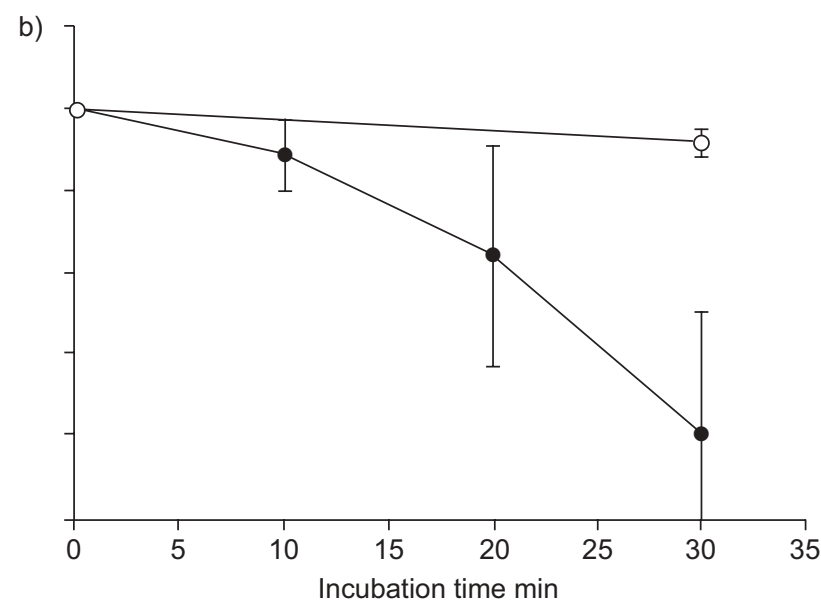

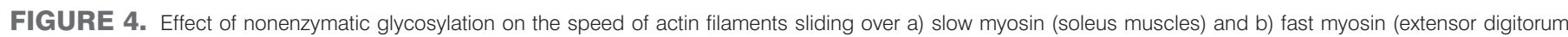

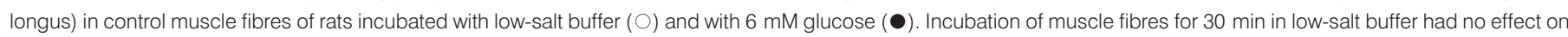

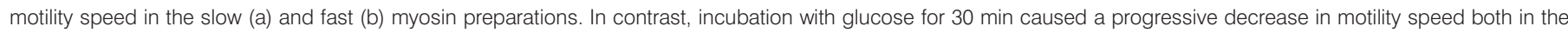
slow (a) and fast (b) myosin preparations $(p<0.05)$. Data are presented as mean \pm SD. Reproduced and modified from [170] with permission from the publisher. 
1 and type 2 diabetes [187]. Inhaled insulin can cause small but significant decreases in diffusing capacity and FEV1 [184]. In addition, absorption of inhaled insulin in COPD is unpredictable [184] and, at least in ex-smokers, inhaled insulin might increase the rate of bronchogenic carcinomas [187]. Whether inhaled insulin should be even considered in diabetic patients with COPD has become a moot point: in 2007 inhaled insulin was discontinued as a result of poor market acceptance [187].

The oral anti-hyperglycaemic agent, metformin, is thought to increase the risk of lactic acidosis, and is considered contraindicated in chronic hypoxaemic conditions [188]. Despite these concerns, a recent meta-analysis of 206 trials revealed no cases of fatal or nonfatal lactic acidosis in 47,846 patient-yrs of metformin use or in 38,221 patients-yrs in the non-metformin group [188].

\section{COPD AND THYROID DISEASES}

The thyroid hormone regulates the metabolism of proteins, lipids and carbohydrates, and controls the activity of membrane-bound enzymes [189, 190]. This hormone can also regulate the transcription of numerous genes encoding both myofibrillar and calcium-regulatory proteins in myofibres (table 2) [191, 192]. The thyroid hormone enhances mitochondrial oxidation and, thus, augments metabolic rate [193]. This effect on metabolic rate is probably responsible for the association between the thyroid hormone and respiratory drive [194].

Limited data on the prevalence of thyroid diseases among patients with COPD are available $[195,196]$. Yet, several characteristics of patients with COPD could potentially increase their likelihood of developing hypothyroidism and hyperthyroidism.

\section{COPD and hypothyroidism: prevalence/risk factors}

Impaired thyroid function can present as subclinical hypothyroidism, overt hypothyroidism and nonthyroidal illness syndrome. Of these, nonthyroidal illness syndrome is the most common in COPD [195], being reported in $20 \%$ of stable patients [195] and 70\% of patients experiencing an exacerbation [195]. Patients with nonthyroidal illness syndrome have decreased levels of the biologically active hormone triiodothyronine (T3) and normal or decreased levels of the prohormone thyroxine (T4) [197]. Serum levels of the TSH are

\section{TABLE 2 Muscle genes responsive to thyroid hormone}

$\mathrm{Na}^{+} / \mathrm{K}^{+}$ATPase

Myosin heavy chain isoforms

Sarcoplasmic reticulum $\mathrm{Ca}^{2+}$ ATPase (SERCA 2)

Phospholamban

Adenylyl cyclase

Voltage-gated $\mathrm{K}^{+}$channels (Kv 1.5, 4.2, 4.3)

$\beta_{1}$-adrenergic receptors

Guanine nucleotide regulatory protein $\left(\mathrm{G}_{\mathrm{s}}\right)$

$\mathrm{Na}^{+} / \mathrm{Ca}^{+}$exchanger (NCX)

Reproduced and modified from [191] with permission from the publisher. usually normal, though they can be low in the most severely ill patients [197]. In the past, patients with nonthyroidal illness syndrome were said to have euthyroid sick syndrome. The latter nomenclature, however, is now considered inappropriate because it is not clear whether these patients are in fact euthyroid in those tissues that are targets for the action of the thyroid hormone [197]. To date it is impossible to state which patient with nonthyroidal illness syndrome, if any, might benefit from treatment, nor what that treatment should be [198]. It is not known if nonthyroidal illness syndrome is a favourable compensatory mechanism to offset catabolism and protein breakdown or if it is an unfavourable adaptation with resultant biochemical hypothyroidism [195]. Severity of airway obstruction, hypoxaemia, systemic inflammation and glucocorticoids may predispose to develop subclinical hypothyroidism, overt hypothyroidism and nonthyroidal illness syndrome.

\section{Severity of airway obstruction}

Compared with moderate COPD, patients with severe COPD (FEV1 $<50 \%$ ) demonstrate reductions in total $\mathrm{T} 3$ and in the $\mathrm{T} 3 /$ $\mathrm{T} 4$ ratio (a marker of peripheral conversion of the prohormone (T4) to the active cellular form of the thyroid hormone (T3)) [195]. In addition, low FEV1 is associated with low basal and stimulated levels of thyroid stimulating hormone (TSH) [199].

\section{Chronic hypoxaemia}

It is controversial whether hypoxaemia impairs the TSH response to exogenous thyroid releasing hormone (TRH) in COPD $[141,200]$. In patients with stable severe COPD, chronic hypoxaemia is associated with a decrease in the peripheral conversion of T4 to the biologically active hormone T3 [196].

\section{Systemic inflammation}

Patients with COPD can present with increased systemic levels of inflammatory cytokines such as IL- 6 , IL- 1 and TNF- $\alpha$ [42, 195]. These cytokines can inhibit the synthesis or secretion of TSH, T3 and thyroid hormone-binding proteins, and can decrease the mRNA for the hepatic enzyme iodothyronine deiodinase type 1; an enzyme that converts T4 to T3 [197, 198]. Notwithstanding these observations, the impact of inflammatory cytokines on thyroid function in patients with COPD is controversial [195, 196].

\section{Glucocorticoids}

In 25 patients with stable COPD, serum T4 levels were inversely related to the dose of oral prednisone [201]. Glucocorticoids may decrease circulating thyroid hormone by decreasing serum TSH [202-205], by redistributing T4 and T3 in the vascular and tissue compartments [206] and by decreasing peripheral conversion of T4 to T3 [207]. Hypothyroidism, when present, can interfere with the metabolism of glucocorticoids by increasing the area-under-the-curve and by delaying the time-topeak of plasma concentrations of oral prednisone [208]. In contrast, inhaled glucocorticoids do not appear to affect thyroid function [196].

\section{COPD and hypothyroidism: functional consequences}

When present, hypothyroidism can decrease respiratory drive, respiratory muscle function, exercise capacity, and increase the risk for sleep disordered breathing in COPD. 


\section{Respiratory muscle function/respiratory drive}

Hypothyroidism can cause inspiratory and expiratory muscle weakness in patients with [209] and without COPD [210]. Weakness is proportional to the severity of hypothyroidism [210] and is reversed by replacement therapy [209, 210]. Weakness might result from decreased expression of Type IIb myosin heavy chains (table 1) [192], phrenic nerve neuropathy [211] or decreased neuromuscular transmission secondary to a decrease in the planar areas of nerve terminals and end-plates of type I and IIa fibres [212]. Although neuromuscular transmission is decreased at rest, transmission is increased during repetitive contractions [212].

It is unclear whether the respiratory muscle weakness can cause chronic or acute-on-chronic alveolar hypoventilation [209], or even need for prolonged mechanical ventilation [213, 214]. In the few series of hypothyroid patients who developed ventilatory failure $[213,214]$ it is impossible to differentiate the contributions of respiratory muscle weakness and decreased respiratory drive [215]. Several mechanisms have been postulated as risk factors for the development of alveolar hypoventilation in hypothyroidism (table 3) [213, 216].

\section{Exercise capacity}

Exercise tolerance and maximal oxygen uptake are decreased in patients with COPD and overt [209] or subclinical hypothyroidism [217]. Impaired muscle energy metabolism, resulting from a defect in glycogen breakdown or mitochondrial function [217], hypothyroid myopathy with the characteristic type II fibre atrophy and large type I fibres [218], and impaired gas exchange [209], systolic function [219] and ventricular relaxation [219], probably contributes to the reduced exercise capacity in these patients.

\section{Sleep-disordered breathing}

High prevalence of sleep-disordered breathing (mainly obstructive in nature) has been reported in hypothyroid patients with [209] and without COPD [220-222]. In these patients, sleep-disordered breathing is largely reversible with replacement therapy [222]. Potential mechanisms of sleepdisordered breathing include obesity, mucoprotein deposition

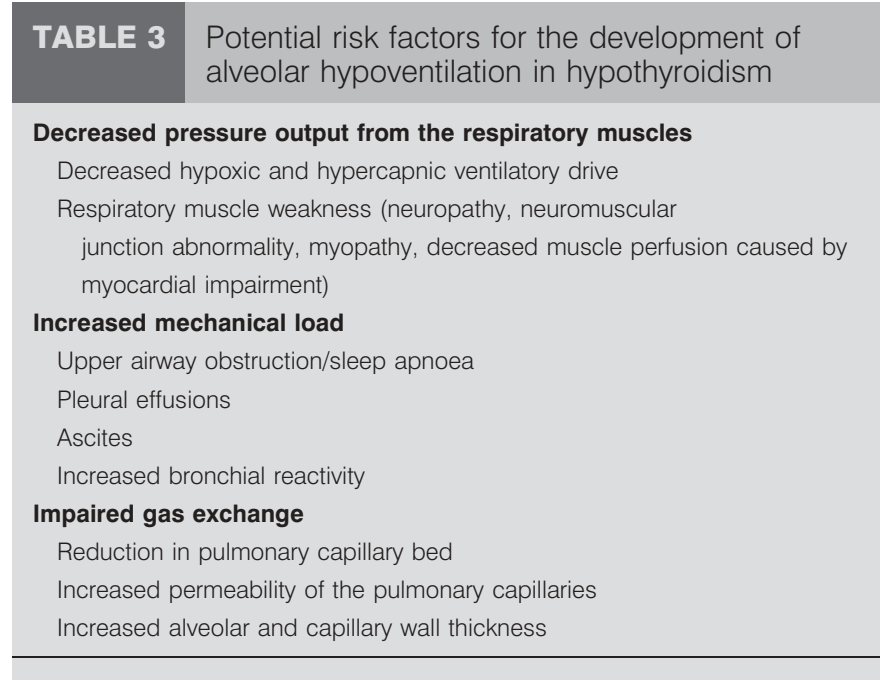

in the upper airway, upper airway myopathy and decreased ventilatory drive [220-224].

\section{COPD and hypothyroidism: treatment}

Hypothyroidism in patients with COPD should be treated in the same manner as in patients without COPD [225]. Patients who also have obstructive sleep apnoea and coronary artery disease require particular attention. In this situation, thyroid replacement should be implemented with care because it causes an increase in myocardial oxygen consumption [226]. During an apnoeic episode, hypoxaemia is further increased in patients with COPD. In the presence of coronary artery disease, these changes can trigger ischaemic events [224].

\section{COPD and hyperthyroidism: prevalence/risk factors}

The prevalence of subclinical [219] and overt hyperthyroidism among patients with COPD is unknown. That hyperthyroidism is more prevalent among former and current smokers [227] raises the possibility that hyperthyroidism may be more prevalent in COPD than in the general population [228].

\section{COPD and hyperthyroidism: functional consequences}

Hyperthyroidism may impair respiratory muscle function, respiratory mechanics and exercise capacity in COPD.

\section{Respiratory muscle function}

Hyperthyroidism causes inspiratory and expiratory muscle weakness in COPD [210, 229-231]. The weakness is proportional to the severity of hyperthyroidism [210] and it can be reversed by 3-9 months of antithyroid therapy [210, 229, 231-233].

Enhanced proteolysis through the activation of a proteasomedependent pathway (fig. 5) [234] and oxidative modification of myofibrillar proteins contribute to diaphragmatic atrophy [235] and weakness in hyperthyroidism [235, 236]. Proteolysis triggered by excess T3 levels [234, 236] can be enhanced by administration of glucocorticoids [16]. $\beta$-Adrenergic blockade can rapidly reverse much of (limb) muscle weakness in hyperthyroidism [237], suggesting that reversible changes in calcium handling and cyclic adenosine monophosphatemediated contractile function contributes to hyperthyroidassociated myopathy [191]. Lastly, hyperthyroid-associated neuropathy may contribute to the weakness [191, 238].

\section{Respiratory mechanics}

Some [233, 239] but not all investigators [229, 240] have reported decreased lung compliance in hyperthyroidism. The mechanisms are unclear [233, 239]. Decreased lung compliance $[233,239]$ and muscle strength [210, 229-231] probably contribute to the mild reduction in vital capacity seen in some patients [210, $229,230,233,239-242]$. The reduction in vital capacity is reversed by antithyroid therapy [210, 229, 230, 233, 241]. It is not known if hyperthyroid patients with COPD experience worsening in airway obstruction, as reported in some patients with severe asthma [243-245].

\section{Respiratory failure}

Hyperthyroid patients are at increased risk for respiratory failure [246] because of decreased respiratory muscle performance [210], decreased lung compliance [233, 239], increased ventilatory requirements [241], increased peripheral and central chemoreceptor sensitivity [231], increased respiratory 
Inactive Ub

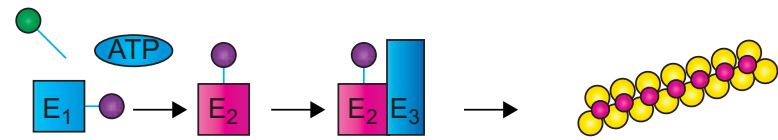

Activated Ub

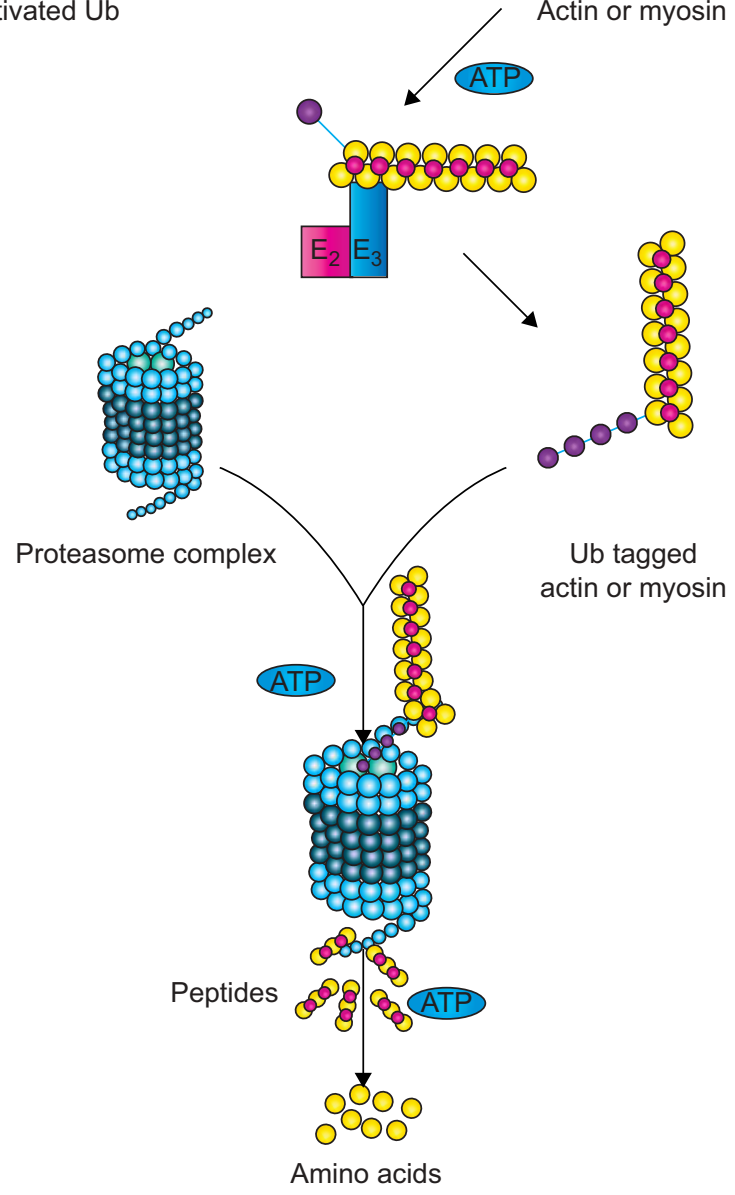

FIGURE 5. Ubiquitin-proteasome degradation of contractile proteins. The first step in degradation of actin and myosin is activation of ubiquitin (Ub) by a first enzyme, $E_{1}$; a process requiring ATP. Activated Ub interacts with a second enzyme, $E_{2}$, a carrier protein. $U b$ and $E_{2}$ join a third enzyme, $E_{3}$. $E_{3}$ transfers activated $U b$ to actin and myosin. The cycle is repeated until a chain of $\mathrm{Ub}$ is bound to the contractile proteins. The chain of $\mathrm{Ub}$ binds to one end of a proteasome complex in a process requiring ATP. The $\mathrm{Ub}$ chain is subsequently removed (allowing reuse of $\mathrm{Ub}$ ), and actin and myosin are unfolded and pushed into the core of the proteasome. Multiple enzymes within the core degrade actin and myosin into small peptides. The peptides are extruded from the proteasome and degraded to amino acids by peptidases in the cytoplasm. The ubiquitin-proteasome pathway degrades many proteins other than actin and myosin. Reproduced and modified from [15] with permission from the publisher.

effective impedance [231], and impaired cardiovascular performance [247].

\section{Exercise capacity}

Exercise capacity is decreased in subclinical [248] and overt hyperthyroidism [229, 242], and can be improved by treatment $[241,242,248]$. Potential mechanisms include decreased limb muscle strength [230, 232], reduced muscle mass [232] decreased fatigue-resistant myofibres [249], reduced skeletal muscle L-carnitine (a carrier of fatty acids in the mitochondria for subsequent oxidation [250]), decreased efficiency of oxygen utilisation [241], reduction in cardiac functional reserve [247, 251], excessive increase in respiratory drive [242], decreased lung volumes [230, 240] and excessive lactate production [247].

\section{COPD and hyperthyroidism: treatment}

Hyperthyroidism in patients with COPD should be treated in the same manner as in patients without COPD [225].

\section{COPD AND RENIN-ANGIOTENSIN-ALDOSTERONE SYSTEM}

The renin-angiotensin-aldosterone system is central to the control of sodium reabsorption by the kidney [252]. Decreases in glomerular filtration rate and sodium delivery to the distal nephron cause release of renin. Renin cleaves angiotensinogen to form angiotensin I [252]. Angiotensin I is then cleaved into angiotensin II by the angiotensin-converting enzyme. Angiotensin II can increase sodium retention through three mechanisms. First, it enhances sodium reabsorption in the proximal tubule. Secondly, it decreases the filtered load of sodium. Thirdly, it stimulates the adrenal cortex to secrete aldosterone. Aldosterone, in turn, increases sodium reabsorption through multiple mechanisms. While activation of the renin-angiotensin-aldosterone system causes sodium retention, sodium excretion is controlled by several natriuretic factors [252]. These factors include a number of natriuretic peptides such as the atrial natriuretic peptide, and the B-type and C-type natriuretic peptides [253]. Natriuretic peptides are primarily synthesised in the heart and brain. Atrial natriuretic peptide and B-type natriuretic peptide increase in response to overload of the extracellular volume. They cause natriuresis, vasodilation and suppress activity of the renin-angiotensinaldosterone system. The $\mathrm{C}$-type natriuretic peptide is primarily vasodilatory.

In the 1970s and 1980s, the group of Farber and Manfredi was among the first to demonstrate that clinically stable hypercapnic patients with COPD often exhibited impaired excretion of sodium and water [254], which was aggravated when oedema was present [255]. They reported upregulation of the reninangiotensin-aldosterone system and vasopressin (which increases water reabsorption in the distal nephron) in COPD $[255,256]$. Increased renin-angiotensin-aldosterone may contribute to sodium retention and increased vasopressin may contribute to hyponatraemia and water retention [255-257]. (Sodium and fluid homeostasis in COPD is reviewed in detail by DE LEeUW and DeEs [252].)

\section{COPD and imbalance of the renin-angiotensin-aldosterone system: risk factors/prevalence}

Most studies of the renin-angiotensin-aldosterone system in COPD have focused on patients who already have evidence of fluid retention. Therefore, there are limited data on the frequency with which this system is activated in the general COPD population (table 4). Development of sodium and water retention in COPD implies poor prognosis [258]. 


\section{COPD and imbalance of the renin-angiotensin-aldosterone system: functional consequences}

Patients with COPD can develop fluid retention when stable $[255,257]$ or during exacerbations [41, 259]. Fluid retention can cause peripheral oedema, ascites and pleural effusions [260]. Right heart pressures can be normal or increased [259]. Cardiac output is often preserved or even increased [41, 259, 261].

The mechanisms responsible for development of fluid retention are complex [252]. The traditional view, that volume overload occurs as a result of right-ventricular failure, itself caused by hypoxia-induced pulmonary vasoconstriction, probably holds true only for certain patients. Growing evidence suggests that renal vasoconstriction is central in the development of fluid retention in patients with COPD [41, 252].

ANAND et al. [41] reported increased pulmonary artery resistance and decreased peripheral vascular resistance in nine hypoxaemic, hypercapnic patients experiencing an exacerbation of COPD and new-onset fluid retention. Cardiac output was normal and mean arterial pressure was reduced. Renal plasma flow and glomerular filtration rate were decreased. Plasma norepinephrine, renin activity, circulating vasopressin and atrial natriuretic peptide concentrations were all increased [41]. The investigators [41] argue that hypercapnia plays a central role by decreasing systemic vascular resistance through a direct effect on systemic arterioles [262, 263]. The increased vascular capacitance will decrease the effective circulating volume and renal blood flow (severe hypoxaemia can also contribute to reduced renal flow [264-267]). A second mechanisms by which hypercapnia may decrease effective circulating volume is through a reduction in precapillary tone [252]. The reduced tone will move the point of filtration equilibrium distally in the capillaries and, consequently, increase extravasation and the loss of plasma volume [252]. Reduction of effective circulating volume will stimulate the sympathetic nervous system, the renin-angiotensin-aldosterone system and vasopressin [260]. To restore intravascular volume and tissue perfusion, the kidney will respond with vasoconstriction and sodium retention (fig. 6) [260]. Hypercapnia may also increase sodium retention by accelerating the renal reabsorption of sodium bicarbonate [255]. The retention of salt and water, with the attendant expansion of the extracellular volume, may be sufficient to increase intracardiac pressures and, with it, it may increase circulatory levels of atrial natriuretic peptide [41]. The atrial natriuretic peptide, with its vasodilator properties, could further reduce systemic vascular resistance. Two additional factors may contribute to fluid retention: $\mathrm{GH}$, which can be increased in patients with COPD [18, 41], can itself activate the renin-angiotensinaldosterone system [255]. Second, the carbon dioxide might directly or indirectly turn on the sodium-hydrogen antiporter in the luminal membrane of proximal tubules [252]. The sodium-hydrogen antiporter, also known as sodiumhydrogen exchanger, is primarily responsible for maintaining the balance of sodium and it is involved in the buffering of respiratory acidosis at the expense of sodium gain (fig. 6) [252]. ANAND et al. [41] argue that persistence of hypercapnia will produce vasodilatation and retention of sodium and water. Administration of diuretics may aggravate the vicious cycle by promoting sodium loss and, thus, further activation of the renin-angiotensin system [260].

The model proposed by ANAND et al. [41] has limitations. First, the investigators fail to reconcile the observation that, after the resolution of the congestive state and normalisation of peripheral vascular resistances, levels of renin, angiotensin and aldosterone remained the same as those recorded during the exacerbation [41]. Secondly, the vasoconstrictor effect of hypercapnia-associated activation of the sympathetic nervous system predominates over the direct vasodilatation effect of hypercapnia (indirect vasoconstriction is absent when the vasomotor centre cannot respond to hypercapnia-induced sympathetic activation or when the vasomotor centre is disconnected from peripheral parts of the sympathetic nervous system) [268]. Thirdly, although most patients with COPD and fluid retention are hypercapnic $[269,270]$, hypercapnia is not a necessary prerequisite for the development of fluid retention in these patients [257, 259]. Lastly, the investigators [41] did not control for sodium intake, and all medications, including diuretics, were continued. Therefore, it is difficult to decipher whether fluid retention was a primary event or secondary to relative cardiac impairment; in the study of ANAND et al. [41], patients did not compensate for the decreased blood pressure with supraphysiologic cardiac output.

Additional observations raise questions about the contributions of hypercapnia, aldosterone and vasopressin to fluid retention. In a study of saline loading of patients with COPD [257], only severity of parasympathetic neuropathy and renal blood flow independently influenced sodium excretion. In patients with stable COPD and fluid retention, normalisation of aldosterone by administration of angiotensin-converting enzyme inhibitors did not improve sodium excretion [271]. In

TABLE 4 Abnormalities of the renin-angiotensin-aldosterone system in chronic obstructive pulmonary disease (COPD)

Mild-to-moderate COPD plus

hypoxaemia, normocapnia and no oedema $(n=20)$
Severe COPD plus hypoxaemia, hypercapnia and no oedema $(n=20)$
Severe COPD plus hypoxaemia, hypercapnia and oedema $(n=25)$
Elevated renin activity
Elevated aldosterone
Elevated vasopressin
5

15

0
80

44

56

Data are presented as \% of patients. Reproduced and modified from [255] with permission from the publisher 


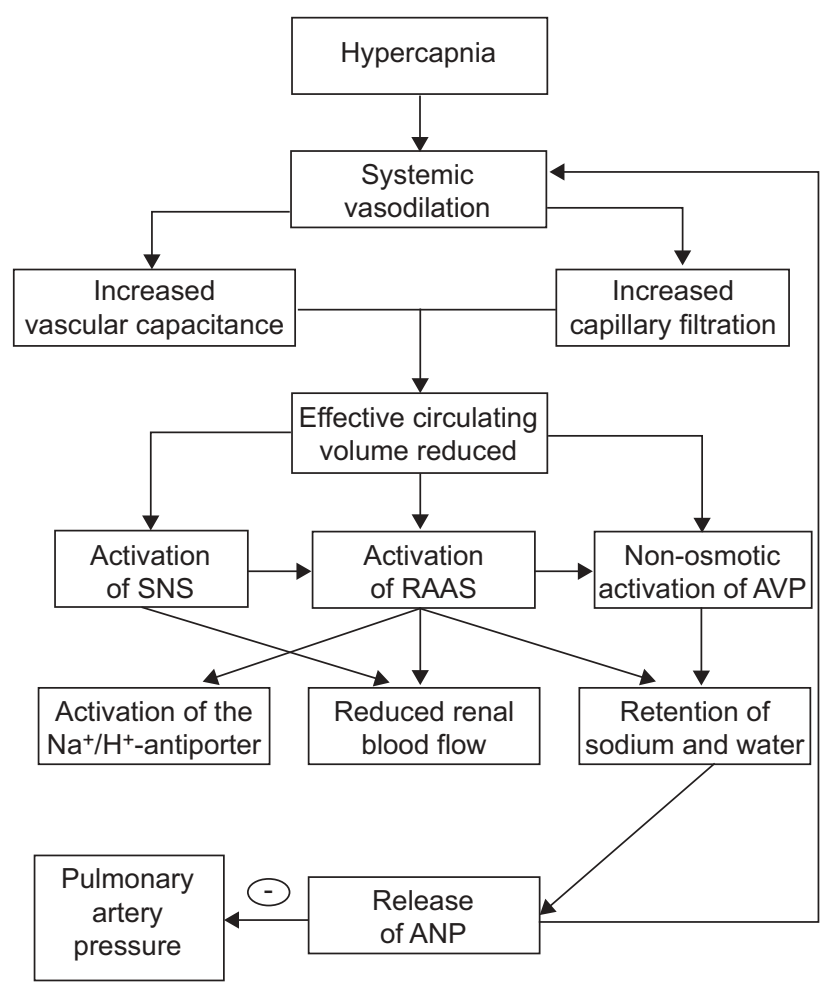

FIGURE 6. Hypothetical pathophysiology of sodium and water retention in chronic obstructive pulmonary disease (see text for details). Not shown are pathways through which atrial natriuretic peptide can modulate fluid homeostasis including dilation of the afferent glomerular arteriole and constriction of the efferent glomerular arteriole with consequent increased glomerular filtration (and thus greater excretion of sodium and water) and inhibition of renin and aldosterone secretion. SNS: sympathetic nervous system; RAAS: renin-angiotensin-aldosterone system; AVP: arginine vasopressin; ANP: atrial natriuretic peptide. Reproduced and modified from [252] with permission from the publisher.

seven mechanically ventilated patients with COPD, changes in plasma hormones during acute hypercapnia were associated with the haemodynamic changes induced by respiratory failure and not to acute hypercapnia per se [272].

A fall in renal blood flow and development of a subclinical parasympathetic neuropathy $[273,274]$, reported in $>35 \%$ of patients with COPD [273], might be more important than aldosterone and vasopressin in causing fluid retention in nonhypoxaemic patients with COPD [257]. Interruption of the parasympathetic afferents can increase vasopressin [275] and, consequently, increase tubular reabsorption of solute-free water. Interruption of vagal pathways can increase intrarenal sympathetic activity with abolition of the reflex fall in sympathetic tone associated with an increase in effective blood volume [257]. A failure to correctly interpret this increase could partly explain the reported impaired sodium excretion [257].

The presence of sympathetic neuropathy [274, 276, 277] may explain why hypercapnia causes a (direct) decrease in peripheral vascular resistance rather than an (indirect) increase through hypercapnia-mediated sympathetic stimulation. A correlation between severity of autonomic neuropathy and hypoxaemia reported by some [273, 274], but not all [276] investigators raises the possibility that autonomic neuropathy is caused by intraneural hypoxaemia [273].

\section{COPD and imbalance of the renin-angiotensin-aldosterone system: therapy}

Few investigators have assessed treatments aimed at reducing fluid retention in COPD [271, 278, 279]. Some suggest postponing diuretics as long as possible [252, 260]. Diuretics can aggravate retention of sodium and water [252, 260] through several pathways including hypoventilation-induced hypocloraemic metabolic alkalosis [280, 281]. Others suggest the use of angiotensin-converting enzyme inhibitors to increase sodium excretion [256]. These agents, however, have inconsistent effects and may increase [282] or have no effect on sodium excretion [271]. Vasopressin levels vary inversely with arterial oxygen tension [252] suggesting that oxygen supplementation may help.

\section{CONCLUSION}

Despite plausibility and increased research, little information is available whether patients with COPD are at increased risk for specific endocrinopathies. The role of the renin-angiotensin-aldosterone system in contributing to oedema in COPD has been studied for more than 30 years, yet our understanding of its contribution is rudimentary. Even less is known about the indications and contraindications for hormone-replacement therapy. No study to assess whether any specific replacement therapy has some effect on COPD progression has been conducted. Cross-fertilisation is source of much creativity in science: Pasteur was a skilled chemist and Darwin a published geologist before they embarked on biology; and Crick was a physicist and Watson a zoologist when they started to research DNA. The paucity of knowledge about the interactions between COPD and the endocrine system indicates that this would be a fertile territory for cross-fertilising collaboration.

\section{SUPPORT STATEMENT}

The present study was supported by grants from the Veterans Administration Research Service.

\section{STATEMENT OF INTEREST}

None declared.

\section{ACKNOWLEDGEMENTS}

The authors would like to thank N. Emanuele and D. J. Leehey for their helpful comments, and J. LaMarre for her help with the biographical search.

\section{REFERENCES}

1 Engelen MP, Schols AM, Baken WC, et al. Nutritional depletion in relation to respiratory and peripheral skeletal muscle function in out-patients with COPD. Eur Respir J 1994; 7: 1793-1797.

2 Laaban JP, Kouchakji B, Dore MF, et al. Nutritional status of patients with chronic obstructive pulmonary disease and acute respiratory failure. Chest 1993; 103: 1362-1368.

3 Schols AM, Soeters PB, Mostert R, et al. Physiologic effects of nutritional support and anabolic steroids in patients with chronic obstructive pulmonary disease. A placebo-controlled randomized trial. Am J Respir Crit Care Med 1995; 152: 1268-1274. 
4 Creutzberg EC, Casaburi R. Endocrinological disturbances in chronic obstructive pulmonary disease. Eur Respir J 2003; 22: Suppl. 46, 76s-80s.

5 Wagner PD. Skeletal muscles in chronic obstructive pulmonary disease: deconditioning, or myopathy? Respirology 2006; 11: 681-686.

6 Philippou A, Maridaki M, Halapas A, et al. The role of the insulin-like growth factor 1 (IGF-1) in skeletal muscle physiology. In Vivo 2007; 21: 45-54.

7 Maggio M, Lauretani F, Ceda GP, et al. Relationship between low levels of anabolic hormones and 6-year mortality in older men: the aging in the Chianti Area (InCHIANTI) study. Arch Intern Med 2007; 167: 2249-2254.

8 Bolster DR, Jefferson LS, Kimball SR. Regulation of protein synthesis associated with skeletal muscle hypertrophy by insulin-, amino acid- and exercise-induced signalling. Proc Nutr Soc 2004; 63: 351-356.

9 Yakar S, Liu JL, Stannard B, et al. Normal growth and development in the absence of hepatic insulin-like growth factor I. Proc Natl Acad Sci USA 1999; 96: 7324-329.

10 Crul T, Spruit MA, Gayan-Ramirez G, et al. Markers of inflammation and disuse in vastus lateralis of chronic obstructive pulmonary disease patients. Eur J Clin Invest 2007; 37: 897-904.

11 Gayan-Ramirez G, Vanderhoydonc F, Verhoeven G, et al. Acute treatment with corticosteroids decreases IGF-1 and IGF-2 expression in the rat diaphragm and gastrocnemius. Am J Respir Crit Care Med 1999; 159: 283-289.

12 Pavelic J, Matijevic T, Knezevic J. Biological \& physiological aspects of action of insulin-like growth factor peptide family. Indian J Med Res 2007; 125: 511-522.

13 Watson RT, Saltiel JE, Pessin JE, et al. Subcellular compartmentalization of insulin signaling processes and GLUT4 trafficking events. In: Saltiel AR, Pessin JE. Mechanisms of insulin action, 1st Edn. New York, Springer Science, 2007; pp. 33-51.

14 Doucet M, Russell AP, Leger B, et al. Muscle atrophy and hypertrophy signaling in patients with chronic obstructive pulmonary disease. Am J Respir Crit Care Med 2007; 176: 261-269.

15 Laghi F, Tobin MJ. Disorders of the respiratory muscles. Am J Respir Crit Care Med 2003; 168: 10-48.

16 Sacheck JM, Ohtsuka A, McLary SC, et al. IGF-I stimulates muscle growth by suppressing protein breakdown and expression of atrophy-related ubiquitin ligases, atrogin-1 and MuRF1. Am J Physiol Endocrinol Metab 2004; 287: E591-E601.

17 Singleton JR, Baker BL, Thorburn A. Dexamethasone inhibits insulin-like growth factor signaling and potentiates myoblast apoptosis. Endocrinology 2000; 141: 2945-2950.

18 Scalvini S, Volterrani M, Vitacca M, et al. Plasma hormone levels and haemodynamics in patients with chronic obstructive lung disease. Monaldi Arch Chest Dis 1996; 51: 380-386.

19 Leach RM, Forsling ML. The effect of changes in arterial PCO2 on neuroendocrine function in man. Exp Physiol 2004; 89: 287-292.

20 Marcell TJ. Sarcopenia: causes, consequences, and preventions. J Gerontol A Biol Sci Med Sci 2003; 58: M911-M916.

21 Marcell TJ, Harman SM, Urban RJ, et al. Comparison of GH, IGF-I, and testosterone with mRNA of receptors and myostatin in skeletal muscle in older men. Am J Physiol Endocrinol Metab 2001; 281: E1159-E1164.

22 Frutos MG, Cacicedo L, Fernandez C, et al. Insights into a role of $\mathrm{GH}$ secretagogues in reversing the age-related decline in the GH/IGF-I axis. Am J Physiol Endocrinol Metab 2007; 293: E1140-E1152.

23 Leifke E, Gorenoi V, Wichers $\mathrm{C}$, et al. Age-related changes of serum sex hormones, insulin-like growth factor-1 and sex-hormone binding globulin levels in men: cross-sectional data from a healthy male cohort. Clin Endocrinol (Oxf) 2000; 53: 689-695.
24 Spencer JB, Klein M, Kumar A, et al. The age-associated decline of androgens in reproductive age and menopausal Black and White women. J Clin Endocrinol Metab 2007; 92: 4730-4733.

25 Awede B, Thissen J, Gailly P, et al. Regulation of IGF-I, IGFBP-4 and IGFBP-5 gene expression by loading in mouse skeletal muscle. FEBS Lett 1999; 461: 263-267.

26 Nindl BC, Alemany JA, Kellogg MD, et al. Utility of circulating IGF-I as a biomarker for assessing body composition changes in men during periods of high physical activity superimposed upon energy and sleep restriction. J Appl Physiol 2007; 103 340-346.

27 Donahue SP, Phillips LS. Response of IGF-1 to nutritional support in malnourished hospital patients: a possible indicator of short-term changes in nutritional status. Am J Clin Nutr 1989; 50: 962-969.

28 Decramer M, Lacquet LM, Fagard R, et al. Corticosteroids contribute to muscle weakness in chronic airflow obstruction. Am J Respir Crit Care Med 1994; 150: 11-16.

29 Saudny-Unterberger H, Martin JG, Gray-Donald K. Impact of nutritional support on functional status during an acute exacerbation of chronic obstructive pulmonary disease. Am J Respir Crit Care Med 1997; 156: 794-799.

30 Solomon AM, Bouloux PM. Modifying muscle mass - the endocrine perspective. J Endocrinol 2006; 191: 349-360.

31 Kritsch KR, Murali S, Adamo ML, et al. Dexamethasone decreases serum and liver IGF-I and maintains liver IGF-I mRNA in parenterally fed rats. Am J Physiol Regul Integr Comp Physiol 2002; 282: R528-R536.

32 Fournier M, Huang ZS, Li H, et al. Insulin-like growth factor I prevents corticosteroid-induced diaphragm muscle atrophy in emphysematous hamsters. Am J Physiol Regul Integr Comp Physiol 2003; 285: R34-R43.

33 Horber FF, Haymond MW. Human growth hormone prevents the protein catabolic side effects of prednisone in humans. J Clin Invest 1990; 86: 265-272.

34 Matsushita T, Kanda F, Sugio T, et al. [Growth hormone prevents the steroid myopathy in rats.]. Rinsho Shinkeigaku 1996; 36: 752-756

35 Petrof BJ, Gottfried SB, Eby J, et al. Growth hormone does not prevent corticosteroid-induced changes in rat diaphragm structure and function. J Appl Physiol 1995; 79: 1571-1577.

36 Kanda F, Takatani K, Okuda S, et al. Preventive effects of insulinlike growth factor-I on steroid-induced muscle atrophy. Muscle Nerve 1999; 22: 213-217.

37 Morrison WL, Gibson JN, Scrimgeour C, et al. Muscle wasting in emphysema. Clin Sci (Lond) 1988; 75: 415-420.

38 Benso A, Broglio F, Aimaretti G, et al. Endocrine and metabolic responses to extreme altitude and physical exercise in climbers. Eur J Endocrinol 2007; 157: 733-740.

39 Dundar B, Akcoral A, Saylam G, et al. Chronic hypoxaemia leads to reduced serum IGF-I levels in cyanotic congenital heart disease. J Pediatr Endocrinol Metab 2000; 13: 431-436.

40 Iioka Y, Tatsumi K, Sugito K, et al. Effects of insulin-like growth factor on nitrogen balance during hypoxic exposure. Eur Respir J 2002; 20: 293-299.

41 Anand IS, Chandrashekhar Y, Ferrari R, et al. Pathogenesis of congestive state in chronic obstructive pulmonary disease. Studies of body water and sodium, renal function, hemodynamics, and plasma hormones during edema and after recovery. Circulation 1992; 86: 12-21.

42 Wouters EF. Local and systemic inflammation in chronic obstructive pulmonary disease. Proc Am Thorac Soc 2005; 2: 26-33.

43 Broussard SR, McCusker RH, Novakofski JE, et al. Cytokinehormone interactions: tumor necrosis factor alpha impairs biologic activity and downstream activation signals of the insulin-like growth factor I receptor in myoblasts. Endocrinology 2003; 144: 2988-2996. 
44 Casaburi R, Goren S, Bhasin S. Substantial prevalence of low anabolic hormone levels in COPD patients undergoing rehabilitation. Am J Respir Crit Care Med 1996; 153: A128.

45 Casaburi R, Bhasin S, Cosentino L, et al. Effects of testosterone and resistance training in men with chronic obstructive pulmonary disease. Am J Respir Crit Care Med 2004; 170: 870-878.

46 Itoh T, Nagaya N, Yoshikawa M, et al. Elevated plasma ghrelin level in underweight patients with chronic obstructive pulmonary disease. Am J Respir Crit Care Med 2004; 170: 879-882.

47 Spruit MA, Gosselink R, Troosters T, et al. Muscle force during an acute exacerbation in hospitalised patients with COPD and its relationship with CXCL8 and IGF-I. Thorax 2003; 58: 752-756.

48 Burdet L, de Muralt B, Schutz Y, et al. Administration of growth hormone to underweight patients with chronic obstructive pulmonary disease. A prospective, randomized, controlled study. Am J Respir Crit Care Med 1997; 156: 1800-1806.

49 Debigare $\mathrm{R}$, Marquis $\mathrm{K}$, Cote $\mathrm{CH}$, et al. Catabolic/anabolic balance and muscle wasting in patients with COPD. Chest 2003; 124: 83-89.

50 Koehler F, Doehner W, Hoernig S, et al. Anorexia in chronic obstructive pulmonary disease - association to cachexia and hormonal derangement. Int J Cardiol 2007; 119: 83-89.

51 Lewis MI, Fournier M, Da X, et al. Short-term influences of lung volume reduction surgery on the diaphragm in emphysematous hamsters. Am J Respir Crit Care Med 2004; 170: 753-759.

52 Pape GS, Friedman M, Underwood LE, et al. The effect of growth hormone on weight gain and pulmonary function in patients with chronic obstructive lung disease. Chest 1991; 99: 1495-1500.

53 Pichard C, Kyle U, Chevrolet JC, et al. Lack of effects of recombinant growth hormone on muscle function in patients requiring prolonged mechanical ventilation: a prospective, randomized, controlled study. Crit Care Med 1996; 24: 403-413.

54 Takala J, Ruokonen E, Webster NR, et al. Increased mortality associated with growth hormone treatment in critically ill adults. N Engl J Med 1999; 341: 785-792.

55 Schibler A, von der HR, Birrer P, et al. Prospective randomised treatment with recombinant human growth hormone in cystic fibrosis. Arch Dis Child 2003; 88: 1078-1081.

56 Schnabel D, Grasemann C, Staab D, et al. A multicenter, randomized, double-blind, placebo-controlled trial to evaluate the metabolic and respiratory effects of growth hormone in children with cystic fibrosis. Pediatrics 2007; 119: e1230-e1238.

57 Chahal HS, Drake WM. The endocrine system and ageing. $J$ Pathol 2007; 211: 173-180.

58 Papadakis MA, Grady D, Black D, et al. Growth hormone replacement in healthy older men improves body composition but not functional ability. Ann Intern Med 1996; 124: 708-716.

59 Tentori L, Graziani G. Doping with growth hormone/IGF-1, anabolic steroids or erythropoietin: is there a cancer risk? Pharmacol Res 2007; 55: 359-369.

60 Nagaya N, Itoh T, Murakami S, et al. Treatment of cachexia with ghrelin in patients with COPD. Chest 2005; 128: 1187-1193.

61 Vogiatzis I, Stratakos G, Simoes DC, et al. Effects of rehabilitative exercise on peripheral muscle TNFalpha, IL-6, IGF-I and MyoD expression in patients with COPD. Thorax 2007; 62: 950-956.

62 Rabinovich RA, Figueras M, Ardite E, et al. Increased tumour necrosis factor-alpha plasma levels during moderate-intensity exercise in COPD patients. Eur Respir J 2003; 21: 789-794.

63 Griffin JE, Ojeda SR. Textbook of Endocrine Physiology, 5 ed. New York, Oxford University Press, 2004.

64 Shifren JL, Braunstein GD, Simon JA, et al. Transdermal testosterone treatment in women with impaired sexual function after oophorectomy. N Engl J Med 2000; 343: 682-688.

65 Watanobe H, Hayakawa Y. Hypothalamic interleukin-1 beta and tumor necrosis factor-alpha, but not interleukin-6, mediate the endotoxin-induced suppression of the reproductive axis in rats. Endocrinology 2003; 144: 4868-4875.
66 Griffin JE. Male Reproductive function. In: Griffin JE, Ojeda SR. Textbook of Endocrine Physiology. 5th Edn. New York, Oxford University Press, 2004; pp. 226-248.

67 Rhoden EL, Morgentaler A. Risks of testosterone-replacement therapy and recommendations for monitoring. $N$ Engl J Med 2004; 350: 482-492.

68 Lewis MI, Fournier M, Storer TW, et al. Skeletal muscle adaptations to testosterone and resistance training in men with COPD. J Appl Physiol 2007; 103: 1299-1310.

69 Herbst KL, Bhasin S. Testosterone action on skeletal muscle. Curr Opin Clin Nutr Metab Care 2004; 7: 271-277.

70 Harman SM, Metter EJ, Tobin JD, et al. Longitudinal effects of aging on serum total and free testosterone levels in healthy men. Baltimore Longitudinal Study of Aging. J Clin Endocrinol Metab 2001; 86: 724-731.

71 Gray A, Feldman HA, McKinlay JB, et al. Age, disease, and changing sex hormone levels in middle-aged men: results of the Massachusetts Male Aging Study. J Clin Endocrinol Metab 1991; 73: 1016-1025.

72 Haren MT, Banks WA, Perry Iii HM, et al. Predictors of serum testosterone and DHEAS in African-American men. Int J Androl 2008; 31: 50-59.

73 Snyder PJ. Hypogonadism in elderly men - what to do until the evidence comes. N Engl J Med 2004; 350: 440-442.

74 Biskobing DM. COPD and osteoporosis. Chest 2002; 121: 609-620.

75 Marquis K, Debigare R, Lacasse Y, et al. Midthigh muscle crosssectional area is a better predictor of mortality than body mass index in patients with chronic obstructive pulmonary disease. Am J Respir Crit Care Med 2002; 166: 809-813.

76 Laghi F, Antonescu-Turcu A, Collins E, et al. Hypogonadism in men with chronic obstructive pulmonary disease: prevalence and quality of life. Am J Respir Crit Care Med 2005; 171: 728-733.

77 Kamischke A, Kemper DE, Castel MA, Luthke M, Rolf C, Behre HM, et al. Testosterone levels in men with chronic obstructive pulmonary disease with or without glucocorticoid therapy. Eur Respir J 1998; 11: 41-45.

78 Van Vliet M, Spruit MA, Verleden G, et al. Hypogonadism, quadriceps weakness, and exercise intolerance in chronic obstructive pulmonary disease. Am J Respir Crit Care Med 2005; 172: 1105-1111.

79 Morley JE, Perry HM III. Androgen treatment of male hypogonadism in older males. J Steroid Biochem Mol Biol 2003; 85: 367-373

80 Davison SL, Bell R, Donath S, et al. Androgen levels in adult females: changes with age, menopause, and oophorectomy. J Clin Endocrinol Metab 2005; 90: 3847-3853.

81 Cleland WH, Mendelson CR, Simpson ER. Effects of aging and obesity on aromatase activity of human adipose cells. J Clin Endocrinol Metab 1985; 60: 174-177.

82 Isidori AM, Lenzi A. Risk factors for androgen decline in older males: lifestyle, chronic diseases and drugs. J Endocrinol Invest 2005; 28: 14-22.

83 Karadag F, Ozcan H, Karul AB, et al. Sex hormone alterations and systemic inflammation in chronic obstructive pulmonary disease. Int J Clin Pract 2007; 63: 275-281.

84 Nierman DM, Mechanick JI. Hypotestosteronemia in chronically critically ill men. Crit Care Med 1999; 27: 2418-2421.

85 Semple PD, Beastall GH, Watson WS, et al. Serum testosterone depression associated with hypoxia in respiratory failure. Clin Sci (Lond) 1980; 58: 105-106.

86 English KM, Pugh PJ, Parry H, et al. Effect of cigarette smoking on levels of bioavailable testosterone in healthy men. Clin Sci (Lond) 2001; 100: 661-665.

87 Creutzberg EC, Schols AM. Anabolic steroids. Curr Opin Clin Nutr Metab Care 1999; 2: 243-253.

88 Mealy K, Robinson B, Millette CF, et al. The testicular effects of tumor necrosis factor. Ann Surg 1990; 211: 470-475. 
89 van der PT, Romijn JA, Endert E, et al. Effects of tumor necrosis factor on the hypothalamic-pituitary-testicular axis in healthy men. Metabolism 1993; 42: 303-307.

90 Simpson ER, Clyne C, Rubin G, et al. Aromatase - a brief overview. Annu Rev Physiol 2002; 64: 93-127.

91 Cover PO, Baanah-Jones F, John CD, et al. Annexin 1 (lipocortin 1) mimics inhibitory effects of glucocorticoids on testosterone secretion and enhances effects of interleukin-1beta. Endocrine 2002; 18: 33-39.

92 Wajchenberg BL. Subcutaneous and visceral adipose tissue: their relation to the metabolic syndrome. Endocr Rev 2000; 21: 697-738.

93 Jockenhovel F, Blum WF, Vogel E, et al. Testosterone substitution normalizes elevated serum leptin levels in hypogonadal men. $J$ Clin Endocrinol Metab 1997; 82: 2510-2513.

94 Nystrom F, Ekman B, Osterlund M, et al. Serum leptin concentrations in a normal population and in GH deficiency: negative correlation with testosterone in men and effects of GH treatment. Clin Endocrinol (Oxf) 1997; 47: 191-198.

95 Broglio F, Gottero C, Benso A, et al. Effects of ghrelin on the insulin and glycemic responses to glucose, arginine, or free fatty acids load in humans. J Clin Endocrinol Metab 2003; 88: 4268-4272.

96 Nagaya N, Kojima M, Kangawa K. Ghrelin, a novel growth hormone-releasing peptide, in the treatment of cardiopulmonary-associated cachexia. Intern Med 2006; 45: 127-134.

97 Cohen PG. Obesity in men: The hypogonadal-estrogen receptor relationship and its effect on glucose homeostasis. Med Hypotheses 2008; 70: 358-360.

98 Jones PW, Bosh TK. Quality of life changes in COPD patients treated with salmeterol. Am J Respir Crit Care Med 1997; 155: 1283-1289.

99 Domingo-Salvany A, Lamarca R, Ferrer M, et al. Health-related quality of life and mortality in male patients with chronic obstructive pulmonary disease. Am J Respir Crit Care Med 2002; 166: 680-685.

100 Oga T, Nishimura K, Tsukino M, et al. Analysis of the factors related to mortality in chronic obstructive pulmonary disease: role of exercise capacity and health status. Am J Respir Crit Care Med 2003; 167: 544-549.

101 Lunenfeld B, Nieschlag E. Testosterone therapy in the aging male. Aging Male 2007; 10: 139-153.

102 Osman IM, Godden DJ, Friend JA, et al. Quality of life and hospital re-admission in patients with chronic obstructive pulmonary disease. Thorax 1997; 52: 67-71.

103 Barrett-Connor E, Von Muhlen DG, Kritz-Silverstein D. Bioavailable testosterone and depressed mood in older men: the Rancho Bernardo Study. J Clin Endocrinol Metab 1999; 84: 573-577.

104 Santoro N, Torrens J, Crawford S, et al. Correlates of circulating androgens in mid-life women: the study of women's health across the nation. J Clin Endocrinol Metab 2005; 90: 4836-4845.

105 Hill K, Geist R, Goldstein RS, et al. Anxiety and depression in end-stage COPD. Eur Respir J 2008; 31: 667-677.

106 Jones PW, Quirk FH, Baveystock CM, et al. A self-complete measure of health status for chronic airflow limitation. The St. George's Respiratory Questionnaire. Am Rev Respir Dis 1992; 145: 1321-1327.

107 Berwick DM, Murphy JM, Goldman PA, et al. Performance of a five-item mental health screening test. Med Care 1991; 29: 169-176.

108 Laghi F, Langbein WE, Antonescu-Turcu A, et al. Respiratory and skeletal muscles in hypogonadal men with chronic obstructive pulmonary disease. Am J Respir Crit Care Med 2005; 171: 598-605.

109 Laghi F, Cattapan SE, Jubran A, et al. Is weaning failure caused by low-frequency fatigue of the diaphragm? Am J Respir Crit Care Med 2003; 167: 120-127.

110 Ferguson GT. Effects of cortisone and testosterone on diaphragmatic function and biochemistry in the rabbit. J Appl Physiol 1995; 78: $1459-1468$
111 Levine S, Kaiser L, Leferovich J, et al. Cellular adaptations in the diaphragm in chronic obstructive pulmonary disease. $N$ Engl J Med 1997; 337: 1799-1806.

112 Bagatell CJ, Bremner WJ. Androgens in men - uses and abuses. N Engl J Med 1996; 334: 707-714.

113 Bhasin S, Bagatell CJ, Bremner WJ, et al. Issues in testosterone replacement in older men. J Clin Endocrinol.Metab 1998; 83: 3435-2448.

114 Ferrando AA, Sheffield-Moore M, Yeckel CW, et al. Testosterone administration to older men improves muscle function: molecular and physiological mechanisms. Am J Physiol Endocrinol Metab 2002; 282: E601-E607.

115 Storer TW, Magliano L, Woodhouse L, et al. Testosterone dosedependently increases maximal voluntary strength and leg power, but does not affect fatigability or specific tension. J Clin Endocrinol Metab 2003; 88: 1478-1485.

116 Snyder PJ, Peachey H, Hannoush P, et al. Effect of testosterone treatment on body composition and muscle strength in men over 65 years of age. J Clin Endocrinol Metab 1999; 84: 2647-2653.

117 Wittert GA, Chapman IM, Haren MT, et al. Oral testosterone supplementation increases muscle and decreases fat mass in healthy elderly males with low-normal gonadal status. J Gerontol A Biol Sci Med Sci 2003; 58: 618-625.

118 Snyder PJ, Peachey H, Berlin JA, et al. Effects of testosterone replacement in hypogonadal men. J Clin Endocrinol Metab 2000; 85: 2670-2677.

119 Bhasin S, Woodhouse L, Casaburi R, et al. Older men are as responsive as young men to the anabolic effects of graded doses of testosterone on the skeletal muscle. J Clin Endocrinol Metab 2005; 90: 678-688.

120 Casaburi R, Love RD, Bhasin S, et al. A randomized trial of testosterone supplementation in women with COPD. Am J Respir Crit Care Med 2007; 175: A851.

121 Ferreira IM, Verreschi IT, Nery LE, et al. The influence of 6 months of oral anabolic steroids on body mass and respiratory muscles in undernourished COPD patients. Chest 1998; 114 19-28.

122 Creutzberg EC, Wouters EF, Mostert R, et al. A role for anabolic steroids in the rehabilitation of patients with COPD? A doubleblind, placebo-controlled, randomized trial. Chest 2003; 124 1733-1742.

123 English KM, Mandour O, Steeds RP, et al. Men with coronary artery disease have lower levels of androgens than men with normal coronary angiograms. Eur Heart J 2000; 21: 890-894.

124 Turhan S, Tulunay C, Gulec S, et al. The association between androgen levels and premature coronary artery disease in men. Coron Artery Dis 2007; 18: 159-162.

125 Rosano GM, Sheiban I, Massaro R, et al. Low testosterone levels are associated with coronary artery disease in male patients with angina. Int J Impot Res 2007; 19: 176-182.

126 Guthrie JR, Taffe JR, Lehert P, et al. Association between hormonal changes at menopause and the risk of a coronary event: a longitudinal study. Menopause 2004; 11: 315-322.

127 Young RP, Hopkins R, Eaton TE. Forced expiratory volume in one second: not just a lung function test but a marker of premature death from all causes. Eur Respir J 2007; 30: 616-622.

128 Huiart L, Ernst P, Suissa S. Cardiovascular morbidity and mortality in COPD. Chest 2005; 128: 2640-646.

129 Sidney S, Sorel M, Quesenberry CP Jr, et al. COPD and incident cardiovascular disease hospitalizations and mortality: Kaiser Permanente Medical Care Program. Chest 2005; 128: 2068-2075.

130 Maclay JD, McAllister DA, Macnee W. Cardiovascular risk in chronic obstructive pulmonary disease. Respirology 2007; 12: 634-641.

131 Mannino DM, Thorn D, Swensen A, et al. Prevalence and outcomes of diabetes, hypertension and cardiovascular disease in COPD. Eur Respir J 2008; 32: 962-969. 
132 Iqbal F, Michaelson J, Thaler L, et al. Declining bone mass in men with chronic pulmonary disease: contribution of glucocorticoid treatment, body mass index, and gonadal function. Chest 1999; 116: 1616-1624.

133 Thorevska N, Antonescu-Turcu A, Collins E, et al. Does hypogonadism in men with COPD affect sexual function, depression and bone mineral density? Am J Respir Crit Care Med 2005; 171: A64.

134 Emmelot-Vonk MH, Verhaar HJ, Nakhai Pour HR, et al. Effect of testosterone supplementation on functional mobility, cognition, and other parameters in older men: a randomized controlled trial. JAMA 2008; 299: 39-52.

135 Committee on Assessing the Need for Clinical Trials of Testosterone Replacement Therapy. Executive summary. In Liverman CT, Blazer DG. Testosterone and aging: clinical research directions. Washington, DC, National Academy Press, 2004; pp. 1-10.

136 Tsuji K, Furutama D, Tagami M, et al. Specific binding and effects of dehydroepiandrosterone sulfate (DHEA-S) on skeletal muscle cells: possible implication for DHEA-S replacement therapy in patients with myotonic dystrophy. Life Sci 1999; 65 $17-26$.

137 Morales AJ, Haubrich RH, Hwang JY, et al. The effect of six months treatment with a $100 \mathrm{mg}$ daily dose of dehydroepiandrosterone (DHEA) on circulating sex steroids, body composition and muscle strength in age-advanced men and women. Clin Endocrinol (Oxf) 1998; 49: 421-432.

138 Christiansen JJ, Djurhuus $\mathrm{CB}$, Gravholt $\mathrm{CH}$, et al. Effects of cortisol on carbohydrate, lipid, and protein metabolism: studies of acute cortisol withdrawal in adrenocortical failure. J Clin Endocrinol Metab 2007; 92: 3553-3559.

139 Haren MT, Malmstrom TK, Banks WA, et al. Lower serum DHEAS levels are associated with a higher degree of physical disability and depressive symptoms in middle-aged to older African American women. Maturitas 2007; 57: 347-360.

140 Clark KD, Wardrobe-Wong N, Snashall PD. Endogenous cortisol and lung damage in a predominantly smoking population. Am J Respir Crit Care Med 1999; 159: 755-759.

141 Semple PD, Beastall GH, Watson WS, et al. Hypothalamicpituitary dysfunction in respiratory hypoxia. Thorax 1981; 36: 605-609.

142 Gimenez M, Mohan-Kumar T, Humbert JC, et al. Haematological and hormonal responses to dynamic exercise in patients with chronic airway obstruction. Eur J Clin Invest 1987; 17: 75-80.

143 Mortimer KJ, Tata LJ, Smith CJ, et al. Oral and inhaled corticosteroids and adrenal insufficiency: a case-control study. Thorax 2006; 61: 405-408.

144 Cornil A, Glinoer D, Leclerco R, et al. Adrenocortical and somatotrophic secretions in acute and chronic respiratory insufficiency. Am Rev Respir Dis 1975; 112: 77-81.

145 Schuetz P, Christ-Crain M, Schild U, et al. Effect of a 14-day course of systemic corticosteroids on the hypothalamic-pituitaryadrenal-axis in patients with acute exacerbation of chronic obstructive pulmonary disease. BMC Pulm Med 2008; 8: 1 .

146 Henzen C, Suter A, Lerch E, et al. Suppression and recovery of adrenal response after short-term, high-dose glucocorticoid treatment. Lancet 2000; 355: 542-545.

147 Nair KS, Rizza RA, O'Brien P, et al. DHEA in elderly women and DHEA or testosterone in elderly men. $N$ Engl J Med 2006; 355: 1647-1659.

148 De Meyts P, Palsgaard J, Jensen AM, et al., Insulin and IGF-I Receptor Structure and Binding Mechanism. In: Saltiel AR, Pessin JE. Mechanisms of Insulin Action, 1 ed. New York: Springer Science, 2007; pp. 1-32.

149 Hsia CC, Raskin P. The diabetic lung: relevance of alveolar microangiopathy for the use of inhaled insulin. Am J Med 2005; 118: 205-211.
150 Kahn CR, Saltiel AR. The Molecular Mechanism of Insulin Action and the Regulation of Glucose and Lipid Metabolism. In: Kahn CR, Weir GC, King GL, Jacobson AM, Moses AC, Smith RJ. Joslin's Diabetes Mellitus, 14 ed. Philadelphia: Lippincott Williams and Wilkins, 2005; pp. 145-168.

151 Bennett PH, Knowler WC. Definition, Diagnosis, and Classification of Diabetes Mellitus and Glucose Homeostasis. In: Kahn CR, Weir GC, King GL, Jacobson AM, Moses AC, Smith RJ. Joslin's Diabetes Mellitus, 14 ed. Philadelphia: Lippincott Williams and Wilkins, 2005; pp. 331-340.

152 Antonelli-Incalzi C, Imperiale C, Bellia V, et al. Do GOLD stages of COPD severity really correspond to differences in health status? Eur Respir J 2003; 22: 444-449.

153 Watz H, Waschki B, Boehme C, et al. Extrapulmonary Effects of Chronic Obstructive Pulmonary Disease on Physical Activity. Am J Respir Crit Care Med 2007; 177: 743-751.

154 Walter RE, Beiser A, Givelber RJ, et al. Association between glycemic state and lung function: the Framingham Heart Study. Am J Respir Crit Care Med 2003; 167: 911-916.

155 Ford ES, Mannino DM. Prospective association between lung function and the incidence of diabetes: findings from the National Health and Nutrition Examination Survey Epidemiologic Followup Study. Diabetes Care 2004; 27: 2966-2970.

156 Rana JS, Mittleman MA, Sheikh J, et al. Chronic obstructive pulmonary disease, asthma, and risk of type 2 diabetes in women. Diabetes Care 2004; 27: 2478-2484.

157 Rimm EB, Manson JE, Stampfer MJ, Colditz GA, Willett WC, Rosner B, et al. Cigarette smoking and the risk of diabetes in women. Am J Public Health 1993; 83: 211-214.

158 Rosen P, Nawroth PP, King G, et al. The role of oxidative stress in the onset and progression of diabetes and its complications: a summary of a Congress Series sponsored by UNESCO-MCBN, the American Diabetes Association and the German Diabetes Society. Diabetes Metab Res Rev 2001; 17: 189-212.

159 Barnes PJ. Chronic obstructive pulmonary disease. N Engl J Med 2000; 343: 269-280.

160 Bolton CE, Evans M, Ionescu AA, et al. Insulin resistance and inflammation - A further systemic complication of COPD. COPD 2007; 4: 121-126.

161 Blackburn D, Hux J, Mamdani M. Quantification of the Risk of Corticosteroid-induced Diabetes Mellitus Among the Elderly. J Gen Intern Med 2002; 17: 717-720.

162 Delaunay F, Khan A, Cintra A, et al. Pancreatic beta cells are important targets for the diabetogenic effects of glucocorticoids. $J$ Clin Invest 1997; 100: 2094-2098.

163 Saad MJ, Folli F, Kahn JA, et al. Modulation of insulin receptor, insulin receptor substrate-1, and phosphatidylinositol 3-kinase in liver and muscle of dexamethasone-treated rats. J Clin Invest 1993; 92: 2065-2072.

164 Walters JA, Gibson PG, Wood-Baker R, et al. Systemic corticosteroids for acute exacerbations of chronic obstructive pulmonary disease. Cochrane Database Syst Rev 2009; CD001288.

165 Baker EH, Janaway CH, Philips BJ, et al. Hyperglycaemia is associated with poor outcomes in patients admitted to hospital with acute exacerbations of chronic obstructive pulmonary disease. Thorax 2006; 61: 284-289.

166 Gudmundsson G, Gislason T, Lindberg E, et al. Mortality in COPD patients discharged from hospital: the role of treatment and co-morbidity. Respir Res 2006; 7: 109.

167 Faul JL, Wilson SR, Chu JW, et al. The Effect of an Inhaled Corticosteroid on Glucose Control in Type 2 Diabetes. Clin Med Res 2009; 7: 14-20.

168 Wanke T, Formanek D, Auinger M, et al. Inspiratory muscle performance and pulmonary function changes in insulindependent diabetes mellitus. Am Rev Respir Dis 1991; 143: 97-100. 
169 Wanke T, Paternostro-Sluga T, Grisold W, et al. Phrenic nerve function in type 1 diabetic patients with diaphragm weakness and peripheral neuropathy. Respiration 1992; 59: 233-237.

170 Ramamurthy B, Hook P, Jones AD, et al. Changes in myosin structure and function in response to glycation. FASEB J 2001; 15 : 2415-2422.

171 Polotsky VY, Wilson JA, Haines AS, et al. The impact of insulindependent diabetes on ventilatory control in the mouse. Am J Respir Crit Care Med 2001; 163: 624-632.

172 Brannagan TH, Promisloff RA, McCluskey LF, et al. Proximal diabetic neuropathy presenting with respiratory weakness. J Neurol.Neurosurg.Psychiatry 1999; 67: 539-541.

173 White JE, Bullock RE, Hudgson P, et al. Phrenic neuropathy in association with diabetes. Diabet Med 1992; 9: 954-956.

174 Guazzi M, Brambilla R, De Vita S, et al. Diabetes worsens pulmonary diffusion in heart failure, and insulin counteracts this effect. Am J Respir Crit Care Med 2002; 166: 978-982.

175 Tantucci C, Bottini P, Fiorani C, et al. Cerebrovascular reactivity and hypercapnic respiratory drive in diabetic autonomic neuropathy. J Appl Physiol 2001; 90: 889-896.

176 Muller LM, Gorter KJ, Hak E, et al. Increased risk of common infections in patients with type 1 and type 2 diabetes mellitus. Clin Infect Dis 2005; 41: 281-288.

177 Moretti M, Cilione C, Tampieri A, et al. Incidence and causes of non-invasive mechanical ventilation failure after initial success. Thorax 2000; 55: 819-825.

178 Philips BJ, Meguer JX, Redman J, et al. Factors determining the appearance of glucose in upper and lower respiratory tract secretions. Intensive Care Med 2003; 29: 2204-2210.

179 Philips BJ, Redman J, Brennan A, et al. Glucose in bronchial aspirates increases the risk of respiratory MRSA in intubated patients. Thorax 2005; 60: 761-764.

180 Strotmeyer ES, Cauley JA, Schwartz AV, et al. Diabetes is associated independently of body composition with BMD and bone volume in older white and black men and women: The Health, Aging, and Body Composition Study. J Bone Miner Res 2004; 19: 1084-1091.

181 Hanley DA, Brown JP, Tenenhouse A, et al. Associations among disease conditions, bone mineral density, and prevalent vertebral deformities in men and women 50 years of age and older: cross-sectional results from the Canadian Multicentre Osteoporosis Study. J Bone Miner Res 2003; 18: 784-790.

182 Hofbauer LC, Brueck CC, Singh SK, et al. Osteoporosis in patients with diabetes mellitus. J Bone Miner Res 2007; 22: 1317-1328.

183 Rodbard HW, Blonde L, Braithwaite SS, et al. American Association of Clinical Endocrinologists medical guidelines for clinical practice for the management of diabetes mellitus. Endocr Pract 2007; 13: Suppl. 1, 1-68.

184 McMahon GT, Arky RA. Inhaled insulin for diabetes mellitus. N Engl J Med 2007; 356: 497-502.

185 Standards of medical care in diabetes - 2008. Diabetes Care 2008; 31: Suppl. 1, S12-S54.

186 Burgers JS, Bailey JV, Klazinga NS, et al. Inside guidelines: comparative analysis of recommendations and evidence in diabetes guidelines from 13 countries. Diabetes Care 2002; 25: 1933-1939.

187 Siekmeier R, Scheuch G. Inhaled insulin - does it become reality? J Physiol Pharmacol 2008; 59: Suppl. 6, 81-113.

188 Salpeter S, Greyber E, Pasternak G, et al. Risk of fatal and nonfatal lactic acidosis with metformin use in type 2 diabetes mellitus. Cochrane Database Syst Rev 2006; CD002967.

189 Yen PM. Genomic and nongenomic actions of thyroid hormones. In: Braverman LE, Utiger RD. The thyroid. A fundamental and clinical text, 9 ed. Philadelphia, Lippincott Williams \& Wilkins, 2005; pp. 135-150.
190 Silva JE. Intermediary metabolism and the sympathoadrenal system in hypothyroidism. In: Braverman LE, Utiger RD. The thyroid A fundamental and clinical text, 9 ed. Philadelphia, Lippincott Williams \& Wilkins, 2005; pp. 817-823.

191 Klein I, Ojamaa K. Thyroid (neuro)myopathy. Lancet 2000; 356: 614.

192 Izumo S, Nadal-Ginard B, Mahdavi V. All members of the MHC multigene family respond to thyroid hormone in a highly tissuespecific manner. Science 1986; 231: 597-600.

193 Silva JE. Thermogenesis and sympathoadrenal system in thyrotoxicosis. In: Braverman LE, Utiger RD. The thyroid. A fundamental and clinical text, 9 ed. Philadelphia, Lippincott Williams \& Wilkins, 2005; pp. 607-620.

194 Saaresranta T, Polo O. Hormones and breathing. Chest 2002; 122: 2165-2182.

195 Karadag F, Ozcan H, Karul AB, et al. Correlates of non-thyroidal illness syndrome in chronic obstructive pulmonary disease. Respir Med 2007; 101: 1439-1446.

196 Dimopoulou I, Ilias I, Mastorakos G, et al. Effects of severity of chronic obstructive pulmonary disease on thyroid function. Metabolism 2001; 50: 1397-1401.

197 Wiersinga WM. Nonthyroidal illness. In: Braverman LE, Utiger RD. The thyroid. A fundamental and clinical text, 9 ed Philadelphia, Lippincott Williams \& Wilkins, 2005; pp. 247-263.

$198 \mathrm{Yu}$ J, Koenig RJ. Induction of type 1 iodothyronine deiodinase to prevent the nonthyroidal illness syndrome in mice. Endocrinology 2006; 147: 3580-3585.

199 Bratel T, Wennlund A, Carlstrom K. Impact of hypoxaemia on neuroendocrine function and catecholamine secretion in chronic obstructive pulmonary disease (COPD). Effects of long-term oxygen treatment. Respir Med 2000; 94: 1221-1228.

200 Gow SM, Seth J, Beckett GJ, et al. Thyroid function and endocrine abnormalities in elderly patients with severe chronic obstructive lung disease. Thorax 1987; 42: 520-525.

201 Banks WA, Cooper JA. Hypoxia and hypercarbia of chronic lung disease: minimal effects on anterior pituitary function. South Med J 1990; 83: 290-293.

202 Wilber JF, Utiger RD. The effect of glucocorticoids on thyrotropin secretion. J Clin Invest 1969; 48: 2096-2103.

203 Nicoloff JT, Fisher DA, Appleman MD Jr. The role of glucocorticoids in the regulation of thyroid function in man. $J$ Clin Invest 1970; 49: 1922-1929.

204 Rubello D, Sonino N, Casara D, et al. Acute and chronic effects of high glucocorticoid levels on hypothalamic-pituitary-thyroid axis in man. J Endocrinol Invest 1992; 15: 437-441.

205 Re RN, Kourides IA, Ridgway EC, et al. The effect of glucocorticoid administration on human pituitary secretion of thyrotropin and prolactin. J Clin Endocrinol Metab 1976; 43: 338-346.

206 LoPresti JS, Eigen A, Kaptein E, et al. Alterations in 3,3'5'triiodothyronine metabolism in response to propylthiouracil, dexamethasone, and thyroxine administration in man. J Clin Invest 1989; 84: 1650-1656.

207 Chopra IJ, Williams DE, Orgiazzi J, et al. Opposite effects of dexamethasone on serum concentrations of 3,3',5'-triiodothyronine (reverse T3) and 3,3'5-triiodothyronine (T3). J Clin Endocrinol Metab 1975; 41: 911-920.

208 Bergamaschi S, Rusconi R, Gervasoni M, et al. Pharmacokinetics of prednisone and prednisolone in a case of hypothyroidism: effect of replacement therapy. Steroids 2005; 70: 787-789.

209 Martinez FJ, Bermudez-Gomez M, Celli BR. Hypothyroidism. A reversible cause of diaphragmatic dysfunction. Chest 1989; 96: 1059-1063.

210 Siafakas NM, Salesiotou V, Filaditaki V, et al. Respiratory muscle strength in hypothyroidism. Chest 1992; 102: 189-194.

211 Laroche CM, Cairns T, Moxham J, et al. Hypothyroidism presenting with respiratory muscle weakness. Am Rev Respir Dis 1988; 138: 472-474. 
212 Prakash YS, Gosselin LE, Zhan WZ, et al. Alterations of diaphragm neuromuscular junctions with hypothyroidism. $J$ Appl Physiol 1996; 81: 1240-1248.

213 Datta D, Scalise P. Hypothyroidism and failure to wean in patients receiving prolonged mechanical ventilation at a regional weaning center. Chest 2004; 126: 1307-1312.

214 Pandya K, Lal C, Scheinhorn D, et al. Hypothyroidism and ventilator dependency. Arch Intern Med 1989; 149: 2115-2116.

215 Ladenson PW, Goldenheim PD, Ridgway EC. Prediction and reversal of blunted ventilatory responsiveness in patients with hypothyroidism. Am J Med 1988; 84: 877-883.

216 Wilson WR, Bedell GN. The pulmonary abnormalities in myxedema. J Clin Invest 1960; 39: 42-55.

217 Caraccio N, Natali A, Sironi A, et al. Muscle metabolism and exercise tolerance in subclinical hypothyroidism: a controlled trial of levothyroxine. J Clin Endocrinol Metab 2005; 90: 40574062.

218 Khaleeli AA, Griffith DG, Edwards RH. The clinical presentation of hypothyroid myopathy and its relationship to abnormalities in structure and function of skeletal muscle. Clin Endocrinol (Oxf) 1983; 19: 365-376.

219 Biondi B, Palmieri EA, Lombardi G, et al. Effects of subclinical thyroid dysfunction on the heart. Ann Intern Med 2002; 137: 904-914.

220 Rajagopal KR, Abbrecht PH, Derderian SS, et al. Obstructive sleep apnea in hypothyroidism. Ann Intern Med 1984; 101: 491-494.

221 Lin CC, Tsan KW, Chen PJ. The relationship between sleep apnea syndrome and hypothyroidism. Chest 1992; 102: 1663-1667.

222 Jha A, Sharma SK, Tandon N, et al. Thyroxine replacement therapy reverses sleep-disordered breathing in patients with primary hypothyroidism. Sleep Med 2006; 7: 55-61.

223 Pelttari L, Rauhala E, Polo O, et al. Upper airway obstruction in hypothyroidism. J Intern Med 1994; 236: 177-181.

224 Grunstein RR, Sullivan CE. Sleep apnea and hypothyroidism: mechanisms and management. Am J Med 1988; 85: 775-779.

225 American Association of Clinical Endocrinologists medical guidelines for clinical practice for the evaluation and treatment of hyperthyroidism and hypothyroidism. Endocr Pract 2002; 8: 457-469.

226 Bengel FM, Nekolla SG, Ibrahim T, et al. Effect of thyroid hormones on cardiac function, geometry, and oxidative metabolism assessed noninvasively by positron emission tomography and magnetic resonance imaging. J Clin Endocrinol Metab 2000, 85: $1822-1827$.

227 Asvold BO, Bjoro T, Nilsen TI, et al. Tobacco smoking and thyroid function: a population-based study. Arch Intern Med 2007; 167: 1428-1432.

228 Okutan O, Kartaloglu Z, Onde ME, et al. Pulmonary function tests and thyroid hormone concentrations in patients with chronic obstructive pulmonary disease. Med Princ Pract 2004 13: 126-128.

229 McElvaney GN, Wilcox PG, Fairbarn MS, et al. Respiratory muscle weakness and dyspnea in thyrotoxic patients. Am Rev Respir Dis 1990; 141: 1221-1227.

230 Mier A, Brophy C, Wass JA, et al. Reversible respiratory muscle weakness in hyperthyroidism. Am Rev Respir Dis 1989; 139: 529-533.

231 Pino-Garcia JM, Garcia-Rio F, Diez JJ, et al. Regulation of breathing in hyperthyroidism: relationship to hormonal and metabolic changes. Eur Respir J 1998; 12: 400-407.

232 Norrelund H, Hove KY, Brems-Dalgaard E, et al. Muscle mass and function in thyrotoxic patients before and during medical treatment. Clin Endocrinol (Oxf) 1999; 51: 693-699.

233 Stein M, Kimbel P, Johnson RL. Pulmonary function in hyperthyroidism. J Clin Invest 1961; 40: 348-363.
234 Tawa NE Jr, Odessey R, Goldberg AL. Inhibitors of the proteasome reduce the accelerated proteolysis in atrophying rat skeletal muscles. J Clin Invest 1997; 100: 197-203.

235 Miyashita A, Suzuki S, Suzuki M, et al. Effect of thyroid hormone on in vivo contractility of the canine diaphragm. Am Rev Respir Dis 1992; 145: 1452-1462.

236 Yamada T, Mishima T, Sakamoto M, et al. Myofibrillar protein oxidation and contractile dysfunction in hyperthyroid rat diaphragm. J Appl Physiol 2007; 102: 1850-1855.

237 Olson BR, Klein I, Benner R, et al. Hyperthyroid myopathy and the response to treatment. Thyroid 1991; 1: 137-141.

238 Duyff RF, Van den BJ, Laman DM, et al. Neuromuscular findings in thyroid dysfunction: a prospective clinical and electrodiagnostic study. J Neurol Neurosurg Psychiatry 2000; 68: 750-755.

239 Freedman S. Lung volumes and distensibility, and maximum respiratory pressures in thyroid disease before and after treatment. Thorax 1978; 33: 785-790.

240 Massey DG, Becklake MR, McKenzie JM, et al. Circulatory and ventilatory response to exercise in thyrotoxicosis. $N$ Engl J Med 1967; 276: 1104-1112.

241 Kahaly GJ, Nieswandt J, Wagner S, et al. Ineffective cardiorespiratory function in hyperthyroidism. J Clin Endocrinol Metab 1998; 83: 4075-4078.

242 Small D, Gibbons W, Levy RD, et al. Exertional dyspnea and ventilation in hyperthyroidism. Chest 1992; 101: 1268-1273.

243 Settipane GA, Schoenfeld E, Hamolsky MW. Asthma and hyperthyroidism. J Allergy Clin Immunol 1972; 49: 348-355.

244 White NW, Raine RI, Bateman ED. Asthma and hyperthyroidism. A report of 4 cases. S Afr Med J 1990; 78: 750-752.

245 Ayres J, Clark TJ. Asthma and the thyroid. Lancet 1981; 2: 1110-1111.

246 Ingbar DH. The pulmonary system in hypothyroidism. In: Braverman LE, Utiger RD. The thyroid. A fundamental and clinical text, 9 ed. Philadelphia, Lippincott Williams \& Wilkins, 2005; pp. 781-788.

247 Kahaly GJ, Kampmann C, Mohr-Kahaly S. Cardiovascular hemodynamics and exercise tolerance in thyroid disease. Thyroid 2002; 12: 473-481.

248 Mercuro G, Panzuto MG, Bina A, et al. Cardiac function, physical exercise capacity, and quality of life during long-term thyrotropinsuppressive therapy with levothyroxine: effect of individual dose tailoring. J Clin Endocrinol Metab 2000; 85: 159-164.

249 Caiozzo VJ, Herrick RE, Baldwin KM. Influence of hyperthyroidism on maximal shortening velocity and myosin isoform distribution in skeletal muscles. Am J Physiol 1991; 261: C285-C295.

250 Sinclair C, Gilchrist JM, Hennessey JV, et al. Muscle carnitine in hypo- and hyperthyroidism. Muscle Nerve 2005; 32: 357-359.

251 Klein I, Ojamaa K. Thyroid hormone and the cardiovascular system. N Engl J Med 2001; 344: 501-509.

252 de Leeuw PW, Dees A. Fluid homeostasis in chronic obstructive lung disease. Eur Respir J 2003; 22: Suppl. 46, 33s-40s.

253 Das BB, Solinger R. Role of natriuretic peptide family in cardiovascular medicine. Cardiovasc Hematol Agents Med Chem 2009; 7: 29-42.

254 Farber MO, Bright TP, Strawbridge RA, et al. Impaired water handling in chronic obstructive lung disease. J Lab Clin Med 1975; 85: 41-49.

255 Farber MO, Roberts LR, Weinberger $\mathrm{MH}$, et al. Abnormalities of sodium and $\mathrm{H} 2 \mathrm{O}$ handling in chronic obstructive lung disease Arch Intern Med 1982; 142: 1326-1330.

256 Farber MO, Weinberger MH, Robertson GL, et al. Hormonal abnormalities affecting sodium and water balance in acute respiratory failure due to chronic obstructive lung disease. Chest 1984; 85: 49-54.

257 Stewart AG, Waterhouse JC, Billings CG, et al. Hormonal, renal, and autonomic nerve factors involved in the excretion of sodium 
and water during dynamic salt and water loading in hypoxaemic chronic obstructive pulmonary disease. Thorax 1995; 50: 838-845.

258 Renzetti AD Jr, McClement JH, Litt BD. The Veterans Administration cooperative study of pulmonary function. 3 . Mortality in relation to respiratory function in chronic obstructive pulmonary disease. Am J Med 1966; 41: 115-129.

259 Weitzenblum E, Apprill M, Oswald M, et al. Pulmonary hemodynamics in patients with chronic obstructive pulmonary disease before and during an episode of peripheral edema. Chest 1994; 105: 1377-1382.

260 Wouters EF. Management of severe COPD. Lancet 2004; 364: 883-895.

261 Macnee W. Right ventricular function in cor pulmonale. Cardiology 1988; 75: Suppl. 1, 30-40.

262 Physiology of Respiration, 2 ed. Chicago: Year Book Medical Publishers, 1974.

263 Wendling MG, Eckstein JW, Abboud FM. Cardiovascular responses to carbon dioxide before and after $\beta$-adrenergic blockade. J Appl Physiol 1967; 22: 223-226.

264 Baudouin SV. Oedema and cor pulmonale revisited. Thorax 1997; 52: 401-402.

265 Baudouin SV, Bott J, Ward A, et al. Short term effect of oxygen on renal haemodynamics in patients with hypoxaemic chronic obstructive airways disease. Thorax 1992; 47: 550-554.

266 Howes TQ, Deane CR, Levin GE, et al. The effects of oxygen and dopamine on renal and aortic blood flow in chronic obstructive pulmonary disease with hypoxaemia and hypercapnia. Am J Respir Crit Care Med 1995; 151: 378-383.

267 Sharkey RA, Mulloy EM, O'Neill SJ. The acute effects of oxygen and carbon dioxide on renal vascular resistance in patients with an acute exacerbation of COPD. Chest 1999; 115: 1588-1592.

268 Laghi F, Tobin MJ. Indications for Mechanical Ventilation. In: Tobin MJ. Principles and Practice of Mechanical Ventilation. 2nd Edn. New York, Mc Graw Hill, 2006; pp. 129-162.

269 White RJ, Woodings DF. Impaired water handling in chronic obstructive airways disease. Br Med J 1971; 2: 561-563.

270 Skwarski K, Lee M, Turnbull L, et al. Atrial natriuretic peptide in stable and decompensated chronic obstructive pulmonary disease. Thorax 1993; 48: 730-735.
271 Stewart AG, Waterhouse JC, Billings CG, et al. Effects of angiotensin converting enzyme inhibition on sodium excretion in patients with hypoxaemic chronic obstructive pulmonary disease. Thorax 1994; 49: 995-998.

272 Chabot F, Mertes PM, Delorme N, et al. Effect of acute hypercapnia on alpha atrial natriuretic peptide, renin, angiotensin II, aldosterone, and vasopressin plasma levels in patients with COPD. Chest 1995; 107: 780-786.

273 Stewart AG, Waterhouse JC, Howard P. Cardiovascular autonomic nerve function in patients with hypoxaemic chronic obstructive pulmonary disease. Eur Respir J 1991; 4: 1207-1214.

274 Stewart AG, Marsh F, Waterhouse JC, et al. Autonomic nerve dysfunction in COPD as assessed by the acetylcholine sweatspot test. Eur Respir J 1994; 7: 1090-1095.

275 Schrier RW, Berl T. Mechanism of the antidiuretic effect associated with interruption of parasympathetic pathways. J Clin Invest 1972; 51: 2613-2620.

276 Chhabra SK, De S. Cardiovascular autonomic neuropathy in chronic obstructive pulmonary disease. Respir Med 2005; 99: 126-133.

277 Chen WL, Chen GY, Kuo CD. Hypoxaemia and autonomic nervous dysfunction in patients with chronic obstructive pulmonary disease. Respir Med 2006; 100: 1547-1553.

278 Mannix ET, Dowdeswell I, Carlone S, et al. The effect of oxygen on sodium excretion in hypoxaemic patients with chronic obstructive lung disease. Chest 1990; 97: 840-844.

279 Farber MO, Weinberger MH, Robertson GL, et al. The effects of angiotensin-converting enzyme inhibition on sodium handling in patients with advanced chronic obstructive pulmonary disease. Am Rev Respir Dis 1987; 136: 862-866.

280 Valli G, Fedeli A, Antonucci R, et al. Water and sodium imbalance in COPD patients. Monaldi Arch Chest Dis 2004; 61: 112-116.

281 Brijker F, Heijdra YF, van den Elshout FJ, et al. Discontinuation of furosemide decreases $\mathrm{PaCO}(2)$ in patients with COPD. Chest 2002; 121: 377-382.

282 Farber MO, Weinberger MH, Robertson GL, et al. The effects of angiotensin-converting enzyme inhibition on sodium handling in patients with advanced chronic obstructive pulmonary disease. Am Rev Respir Dis 1987; 136: 862-866. 